Prepared in cooperation with the

New York State Department of Environmental Conservation

\title{
Groundwater Quality in the Upper Hudson River Basin, New York, 2007
}

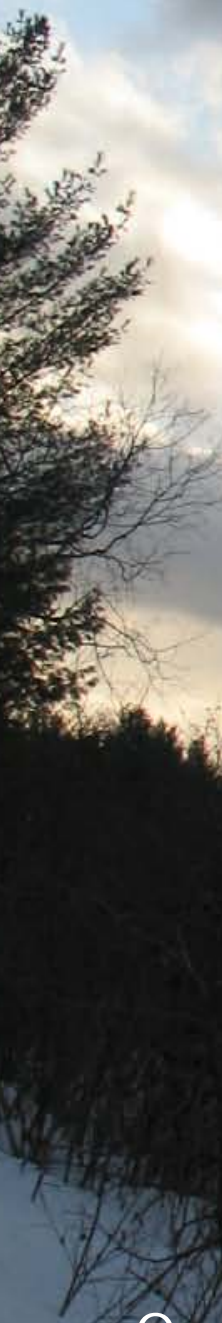

Open-File Report 2009-1240

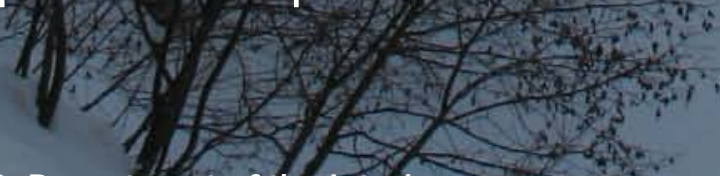

U.S. Department of the Interior

U.S. Geological Survey 
Cover. Winter in the Upper Hudson River Basin 


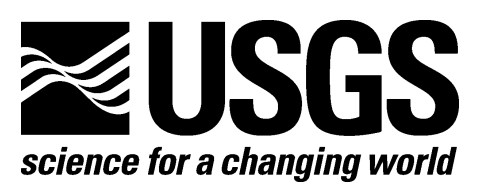

Prepared in cooperation with the

New York State Department of Environmental Conservation

\section{Groundwater Quality in the Upper Hudson River Basin, New York, 2007}

By Elizabeth A. Nystrom

Open-File Report 2009-1240

U.S. Department of the Interior

U.S. Geological Survey 


\section{U.S. Department of the Interior \\ KEN SALAZAR, Secretary}

\section{U.S. Geological Survey \\ Marcia K. McNutt, Director}

U.S. Geological Survey, Reston, Virginia: 2009

For product and ordering information:

World Wide Web: http://www.usgs.gov/pubprod

Telephone: 1-888-ASK-USGS

For more information on the USGS-the Federal source for science about the Earth,

its natural and living resources, natural hazards, and the environment:

World Wide Web: http://www.usgs.gov

Telephone: 1-888-ASK-USGS

Suggested citation:

Nystrom, E.A., 2009, Groundwater quality in the Upper Hudson River Basin, New York, 2007: U.S. Geological Survey

Open-File Report 2009-1240, 37 p., available only at http://pubs.usgs.gov/of/2009/1240/.

Any use of trade, product, or firm names is for descriptive purposes only and does not imply endorsement by the U.S. Government.

Although this report is in the public domain, permission must be secured from the individual copyright owners to reproduce any copyrighted material contained within this report. 


\section{Contents}

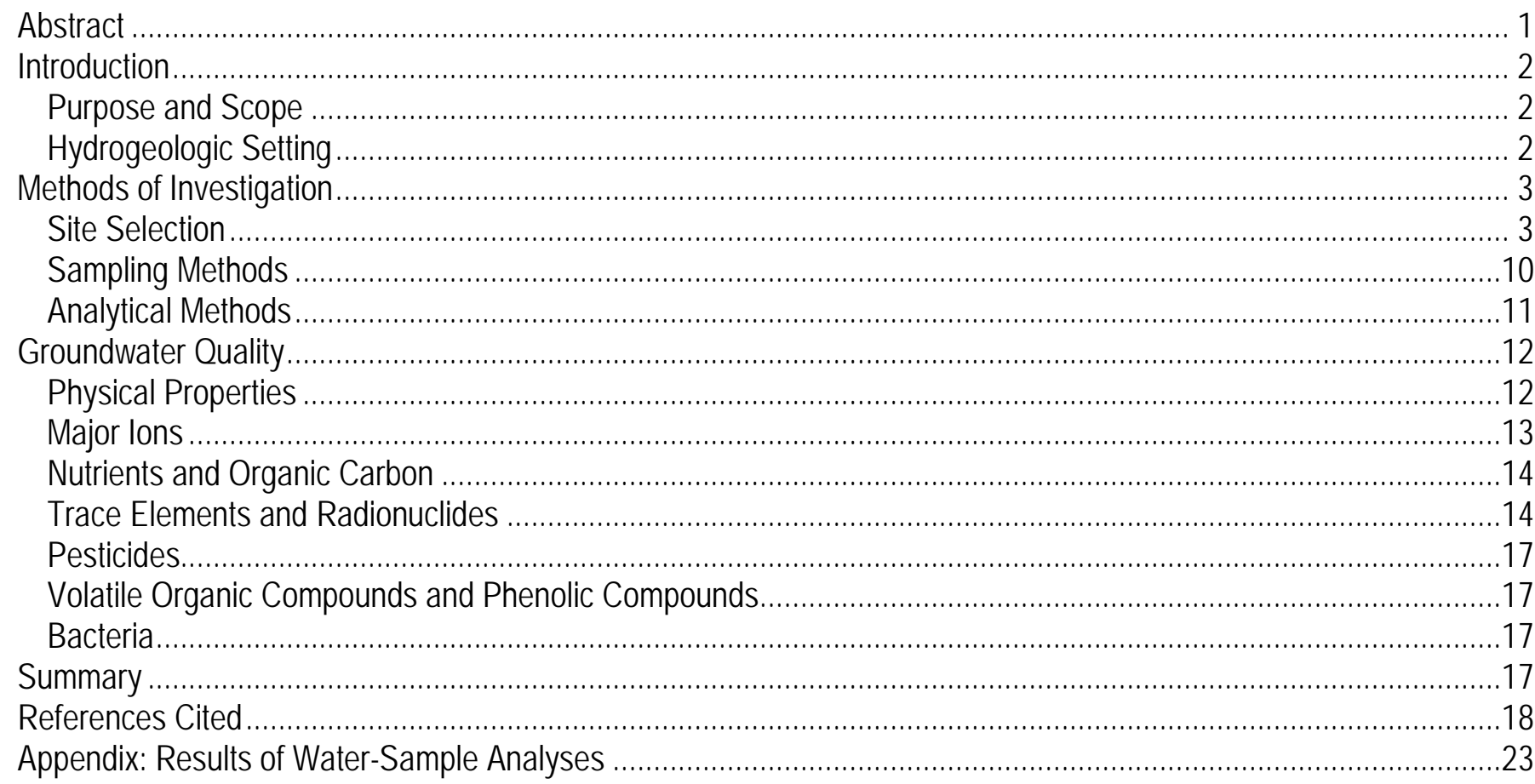

\section{Figures}

1. Map showing principal geographic features of the Upper Hudson River Basin in New York. .......................... 4

2. Map showing topography of the Upper Hudson River Basin in New York, and locations of wells sampled in 2007.

3. Map showing land cover of the Upper Hudson River Basin in New York, and locations of wells sampled in 2007.

4. Map showing generalized bedrock geology of the Upper Hudson River Basin in New York, and locations of wells finished in bedrock sampled in 2007.

5. Map showing generalized surficial geology of the Upper Hudson River Basin in New York, and locations of wells finished in sand and gravel deposits sampled in 2007.

\section{Tables}

1. Information on wells from which water samples were collected in the Upper Hudson River Basin, New York, 2007.

2. Summary of information on wells from which water samples were collected in the Upper Hudson River Basin, New York, 2007.

3. Drinking-water standards and summary statistics for concentrations of major ions in groundwater samples from the Upper Hudson River Basin, New York, 2007.

4. Drinking-water standards and summary statistics for concentrations of nutrients in groundwater samples from the Upper Hudson River Basin, New York, 2007.

5. Drinking-water standards and summary statistics for concentrations of trace elements and radionuclides in groundwater samples from the Upper Hudson River Basin, New York, 2007 
A1. Constituents that were not detected in groundwater samples collected in the Upper Hudson River Basin, New York, 2007.

A2. Physical properties of groundwater samples collected in the Upper Hudson River Basin, New York, 2007....28

A3. Concentrations of major ions in groundwater samples collected in the Upper Hudson River Basin, New York, 2007. 29

A4. Concentrations of nutrients and organic carbon in groundwater samples collected in the Upper Hudson River Basin, New York, 2007. 31

A5. Concentrations of trace elements and radionuclide activities in groundwater samples collected in the Upper Hudson River Basin, New York, 2007. 32

A6. Concentrations of pesticides detected in groundwater samples collected in the Upper Hudson River Basin, New York, 2007.

A7. Concentrations of volatile organic compounds and phenolic compounds detected in groundwater samples collected in the Upper Hudson River Basin, New York, 2007.

A8. Bacteria in groundwater samples collected in the Upper Hudson River Basin, New York, 2007 ....................37 .36 


\section{Conversion Factors, Datum, Abbreviated Water-Quality Units, and Acronyms}

\begin{tabular}{lcl}
\hline \multicolumn{1}{c}{ Multiply } & By & \multicolumn{1}{c}{ To obtain } \\
\hline centimeter $(\mathrm{cm})$ & Length & \\
foot (ft) & 0.3937 & inch (in.) \\
\hline & 0.3048 & meter (m) \\
\hline acre & Area & \\
\hline square mile $\left(\mathrm{mi}^{2}\right)$ & 0.004047 & square kilometer $\left(\mathrm{km}^{2}\right)$ \\
\hline & 2.590 & square kilometer $\left(\mathrm{km}^{2}\right)$ \\
\hline liter (L) & Volume & \\
gallon (gal) & 0.2642 & gallon (gal) \\
\hline & 3.785 & liter $(\mathrm{L})$ \\
\hline gallon per minute (gal/min) & Flow rate & \\
\hline inch per year (in/yr) & 0.06309 & liter per second $(\mathrm{L} / \mathrm{s})$ \\
\hline & 25.4 & millimeter per year $(\mathrm{mm} / \mathrm{yr})$ \\
\hline picocurie per liter (pCi/L) & Radioactivity & \\
\hline
\end{tabular}

Temperature in degrees Celsius $\left({ }^{\circ} \mathrm{C}\right)$ may be converted to degrees Fahrenheit $\left({ }^{\circ} \mathrm{F}\right)$ as follows:

${ }^{\circ} \mathrm{F}=\left(1.8 x^{\circ} \mathrm{C}\right)+32$

Vertical coordinate information is referenced to the North American Vertical Datum of 1988 (NAVD 88).

Horizontal coordinate information is referenced to the North American Datum of 1983 (NAD 83).

Elevation, as used in this report, refers to distance above the vertical datum.

Abbreviated units used in this report:

micrograms per liter $(\mu \mathrm{g} / \mathrm{L})$

micrometer $(\mu \mathrm{m})$

microsiemens per centimeter at 25 degrees Celsius $\left(\mu \mathrm{S} / \mathrm{cm}\right.$ at $\left.25^{\circ} \mathrm{C}\right)$

milligrams per liter $(\mathrm{mg} / \mathrm{L})$

picocuries per liter (pCi/L)

platinum-cobalt units (Pt-Co units) 


$\begin{array}{ll}\text { Acronyms used in this report } \\ \text { AMCL } & \text { Alternative maximum contaminant level } \\ \text { CEAT } & \text { 2-Chloro-6-ethylamino-4-amino-s-triazine } \\ \text { CFU } & \text { Colony-forming units } \\ \text { CIAT } & \text { 2-Chloro-4-isopropylamino-6-amino-s-triazine } \\ \text { cICP-MS } & \text { Collision/reaction cell inductively coupled plasma-mass spectrometry } \\ \text { ESA } & \text { Ethanesulfonic acid } \\ \text { GC-MS } & \text { Gas chromatography-mass spectrometry } \\ \text { GPS } & \text { Global positioning system } \\ \text { HPLC-MS } & \text { High-performance liquid chromatography-mass spectrometry } \\ \text { ICP-AES } & \text { Inductively coupled plasma-atomic emission spectrometry } \\ \text { ICP-MS } & \text { Inductively coupled plasma-mass spectrometry } \\ \text { ICP-OES } & \text { Inductively coupled plasma-optical emission spectrometry } \\ \text { LC-MS } & \text { Liquid chromatography-mass spectrometry } \\ \text { LRL } & \text { Laboratory reporting level } \\ \text { MCL } & \text { Maximum contaminant level } \\ \text { MTBE } & \text { Methyl tert-butyl ether } \\ \text { NWQL } & \text { USGS National Water Quality Laboratory } \\ \text { NYSDEC } & \text { New York State Department of Environmental Conservation } \\ \text { NYSDOH } & \text { New York State Department of Health } \\ \text { OA } & \text { Oxanilic acid } \\ \text { OGRL } & \text { USGS Organic Geochemistry Research Laboratory } \\ \text { OIET } & \text { 2-Hydroxy-4-isopropylamino-6-ethylamino-s-triazine } \\ \text { PERC } & \text { Tetrachloroethene } \\ \text { PVC } & \text { Polyvinyl chloride } \\ \text { SA } & \text { Secondary amide } \\ \text { SDWS } & \text { Secondary drinking-water standards } \\ \text { THM } & \text { Trihalomethane } \\ \text { TTHMs } & \text { Total trihalomethanes } \\ \text { USEPA } & \text { U.S. Environmental Protection Agency } \\ \text { USGS } & \text { U.S. Geological Survey } \\ \text { VOC } & \text { Volatile organic compound } \\ & \end{array}$




\title{
Groundwater Quality in the Upper Hudson River Basin, New York, 2007
}

\author{
By Elizabeth A. Nystrom
}

\begin{abstract}
Water samples were collected from 25 production and domestic wells in the Upper Hudson River Basin (north of the Federal Dam at Troy, N.Y.) from August through November 2007 to characterize the groundwater quality. The Upper Hudson River Basin covers 4,600 square miles in upstate New York, Vermont, and Massachusetts; the study area encompasses the 4,000 square miles that lie within New York. The basin is underlain by crystalline and sedimentary bedrock, including gneiss, shale, and slate; some sandstone and carbonate rocks are present locally. The bedrock in some areas is overlain by surficial deposits of saturated sand and gravel. Of the 25 wells sampled, 13 were finished in sand and gravel deposits, and 12 were finished in bedrock. The samples were collected and processed by standard U.S. Geological Survey procedures and were analyzed for 225 physical properties and constituents, including major ions, nutrients, trace elements, radon-222, pesticides, volatile organic compounds (VOCs), and indicator bacteria.

Water quality in the study area is generally good, but concentrations of some constituents exceeded current or proposed Federal or New York State drinking-water standards; these were: color (1 sample), $\mathrm{pH}$ (2 samples), sodium (5 samples), nitrate plus nitrite (2 samples), aluminum (3 samples), iron (1 sample), manganese (7 samples), radon-222 (11 samples), and bacteria (1 sample). Dissolvedoxygen concentrations in samples from wells finished in sand and gravel [median 5.4 milligrams per liter $(\mathrm{mg} / \mathrm{L})$ ] were greater than those from wells finished in bedrock (median $0.4 \mathrm{mg} / \mathrm{L}$ ). The $\mathrm{pH}$ of all samples was typically neutral or slightly basic (median 7.6); the median water temperature was $9.7^{\circ} \mathrm{C}$. The ions with the highest concentrations were bicarbonate (median $123 \mathrm{mg} / \mathrm{L}$ ) and calcium (median $33.9 \mathrm{mg} / \mathrm{L}$ ). Groundwater in the basin is generally soft to moderately hard (less than or equal to 120 $\mathrm{mg} / \mathrm{L}$ as $\mathrm{CaCO}_{3}$ ) (median hardness $110 \mathrm{mg} / \mathrm{L}$ as $\mathrm{CaCO}_{3}$ ). Concentrations of nitrate plus nitrite in samples from sand and gravel wells (median concentration $0.47 \mathrm{mg} / \mathrm{L}$ as nitrogen) were generally higher than those in samples from bedrock wells (median estimated $0.05 \mathrm{mg} / \mathrm{L}$ as nitrogen), and concentrations in two samples exceeded established drinking-water standards for nitrate $(10 \mathrm{mg} / \mathrm{L}$ as nitrogen). The trace elements with the highest concentrations were strontium [median 217 micrograms per liter $(\mu \mathrm{g} / \mathrm{L})]$ and iron (median $39 \mu \mathrm{g} / \mathrm{L}$ ). The highest radon-222 activities were in samples from bedrock wells [maximum 2,930 picocuries per liter $(\mathrm{pCi} / \mathrm{L})$ ] and 44 percent of all samples exceeded a proposed U.S. Environmental Protection Agency (USEPA) drinking-water standard of 300 pCi/L. Ten pesticides and pesticide degradates were detected among 11 samples at concentrations of $1.47 \mu \mathrm{g} / \mathrm{L}$ or less; most were herbicides or their degradates. Six VOCs were detected among 10 samples at concentrations of $4.2 \mu \mathrm{g} / \mathrm{L}$ or less; these included three trihalomethanes and methyl tert-butyl ether, tetrachloroethene, and toluene. Most detections were in samples from sand and gravel wells and none exceeded drinking-water standards. Total coliform bacteria were detected in only one sample, and fecal coliform bacteria, including Escherichia coli, were not detected in any sample.
\end{abstract}




\section{Introduction}

The Federal Clean Water Act Amendments of 1977 require that states monitor and report biennially on the chemical quality of surface water and groundwater within their boundaries (U.S. Environmental Protection Agency, 1997). In 2002, the U.S. Geological Survey (USGS), in cooperation with the New York State Department of Environmental Conservation (NYSDEC), developed a program to evaluate groundwater quality throughout the major river basins in New York on a rotating basis. The work parallels the NYSDEC Rotating Intensive Basin Study program, which evaluates surface-water quality in 2 or 3 of the 14 major river basins in the State each year. The groundwater-quality program began in 2002 with a pilot study in the Mohawk River Basin (Butch and others, 2003). Sampling was completed in the Chemung River Basin in 2003 (Hetcher-Aguila, 2005); the Lake Champlain (Nystrom, 2006) and Susquehanna River Basins in 2004 (Hetcher-Aguila and Eckhardt, 2006); the St. Lawrence (Nystrom, 2007a), Delaware (Nystrom, 2007b), and Genesee River Basins (Eckhardt and others, 2007) in 2005; and the Mohawk River Basin (Nystrom, 2008) and western New York (Niagara and Allegheny River Basins, and tributaries to Lake Erie and western Lake Ontario) (Eckhardt and others, 2008) in 2006. Studies in the Upper Hudson River Basin and the Oswego, Seneca, and Oneida River Basins (the Finger Lakes area) were completed in 2007.

\section{Purpose and Scope}

This report presents the findings of the 2007 study in the Upper Hudson River Basin, in which 25 groundwater-quality samples were collected from August through November 2007. This report (1) describes the hydrogeologic setting and the methods of site selection, sample collection, and chemical analysis, and (2) discusses the analytical results for physical properties and concentrations of major ions, nutrients, trace elements and radionuclides, pesticides, volatile organic compounds (VOCs), and indicator bacteria. Information about the sampled wells and results of the analyses are presented in the appendix (tables A1 through A8).

\section{Hydrogeologic Setting}

The Upper Hudson River Basin encompasses 4,600 $\mathrm{mi}^{2}$ in upstate New York, Vermont, and Massachusetts and is defined as the part of the Hudson River Basin that lies above the Federal Lock and Dam at Troy, N.Y. (fig. 1). This study included only the 4,000- $\mathrm{mi}^{2}$ part of the basin that lies within New York (fig. 1). The study area contains parts of eight counties (Albany, Essex, Fulton, Hamilton, Rensselaer, Saratoga, Warren, and Washington, fig. 1). Major tributaries to the Upper Hudson River include the Schroon River, Sacandaga River, Batten Kill, and Hoosic River. The Champlain Canal, which connects the Hudson River to Lake Champlain, exits the basin north of Glens Falls. A dam on the Sacandaga River, completed in 1930, created the Great Sacandaga Lake; the dam is used for flow regulation and for power generation.

The highest elevations in the basin are more than 5,000 ft above NAVD 88 in the northern part of the basin (fig. 2). The highest elevation is at the summit of Mount Marcy, on the northern border of the basin (fig. 2). The area of greatest precipitation in the basin is in the Adirondack Park (fig. 1), where the western edge of the basin receives more than $50 \mathrm{in} / \mathrm{yr}$ (Randall, 1996). Land use (fig. 3) reflects the terrain of the basin; developed areas and agriculture are mainly in the low-lying southeastern third of the basin, although sparse urban areas are found in the northern part of the basin along the Interstate Route 87 corridor (fig. 1). The largest urban centers in the basin are the outlying parts of the AlbanySchenectady-Troy area and the cities of Glens Falls and Saratoga Springs (fig. 1). The upland areas of the basin are predominantly forested (Vogelmann and others, 2001) (fig. 3), and much of upland area 
lies within the Adirondack State Park. The Adirondack Park was created in 1892 and has an area of nearly 6 million acres. The New York State Constitution specifies that forest preserve in the parks "shall be forever kept as wild forest lands." About two-thirds of the basin is within the park.

Bedrock in the Upper Hudson River Basin (fig. 4) consists of mostly crystalline and sedimentary rock (Isachsen and others, 2000). The northern part of the basin is underlain by crystalline metamorphic bedrock composed mainly of gneiss; the southern part is underlain mainly by shale and slate, although some sandstones are present. Carbonate bedrock is present in a few locations throughout the basin (fig. 4). The carbonate units are generally the bedrock aquifers with the highest yields in the basin; the sandstone and shale aquifers generally produce small to moderate yields, and the crystalline metamorphic bedrock generally produces the lowest yields (Hammond and others, 1978).

The surficial material throughout the basin was deposited primarily during the Pleistocene epoch, when the Wisconsin glaciers covered most of the Northeast. Till was deposited by glaciers over most of the basin (fig. 5); sand and gravel deposits occur mainly in valleys. Till generally has low yields, whereas sand and gravel, including alluvium, outwash, and ice-contact deposits, form the most productive aquifers in the basin. Wells finished in these coarse deposits may yield as much as 1,000 gal/min (Phillips and Hanchar, 1996).

\section{Methods of Investigation}

The methods used in this study, including (1) well-selection criteria, (2) sampling methods, and (3) analytical methods, were designed to maximize data precision, accuracy, and comparability. Groundwater-sample collection and processing followed standard USGS procedures as documented in the National Field Manual for the Collection of Water-Quality Data (U.S. Geological Survey, variously dated). Samples were analyzed by documented methods at the USGS National Water Quality Laboratory (NWQL) in Denver, Colo., the USGS Organic Geochemistry Research Laboratory (OGRL) in Lawrence, Kans., and New York State Department of Health (NYSDOH)-certified laboratories.

\section{Site Selection}

Wells were selected to provide adequate spatial coverage of the basin; areas of greatest groundwater use were emphasized. The final selection was based on the availability of wellconstruction data and hydrogeologic information for each well and its surrounding area. The study did not target specific municipalities, industries, or agricultural practices. The 25 wells selected for sampling represented forested, rural, residential, and agricultural areas (fig. 3). The characteristics of the wells sampled and the type of land cover surrounding each well are listed in table 1 . The depths of the wells, the geologic units from which samples were collected, and the numbers of production and domestic wells are summarized in table 2.

The 13 domestic wells were selected on the basis of information from the NYSDEC Water Well program, which began in 2000. The program requires that licensed well drillers file a report with NYSDEC containing basic information about each well drilled-such as well and casing depth and diameter, yield, and a hydrogeologic log. Inspection of well-completion reports identified about 200 wells as potential sampling sites. The well owners were sent a letter that included a request for permission to sample the well and a questionnaire about the well. Well owners who granted permission were contacted later by phone to verify well information and to arrange a convenient time for sampling.

Production wells considered for sampling were identified through the U.S. Environmental Protection Agency (USEPA) Safe Drinking Water Information System and the NYSDEC Water Well program. Town officials and (or) water managers were sent letters requesting permission to sample a 


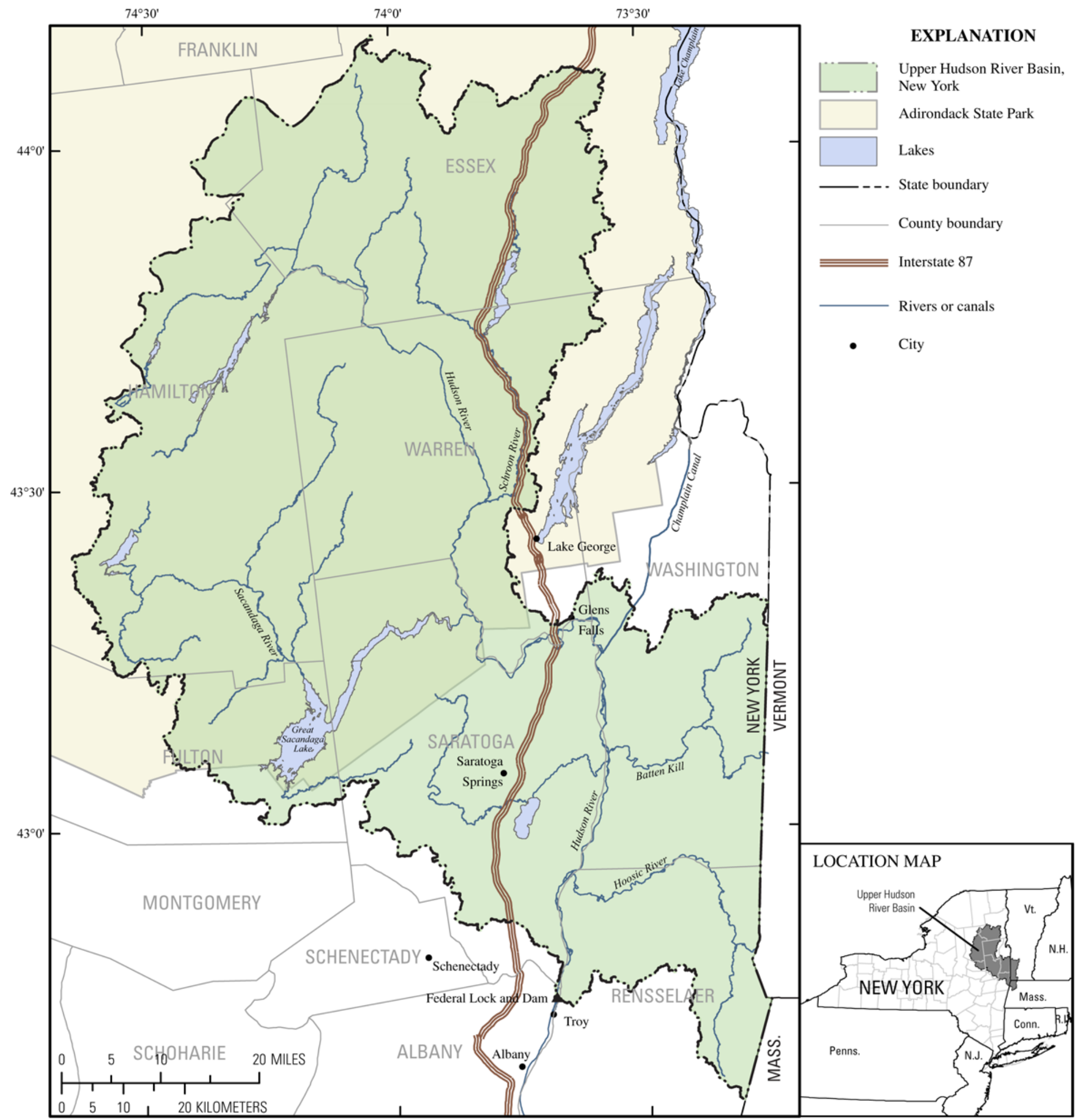

Base from U.S. Geological Survey digital data, 1983, 1:100,000 Universal Transverse Mercator projection

Hydrology from National Hydrography Dataset Zone 18

Figure 1. Principal geographic features of the Upper Hudson River Basin in New York. 


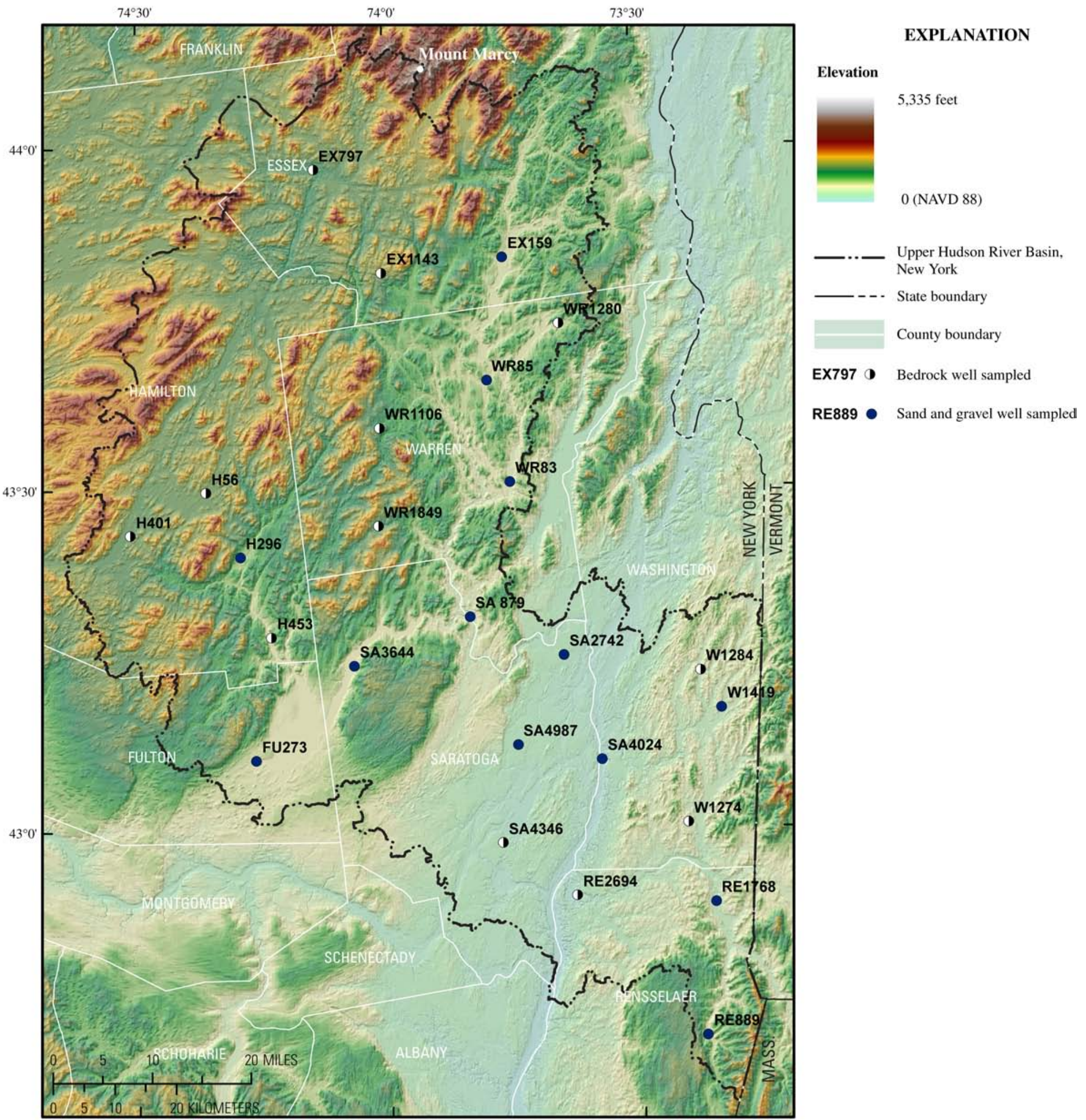

Base from U.S. Geological Survey digital data, 1983, 1:100,000 Universal Transverse Mercator projection

Elevations from National Elevation Dataset, U.S. Geological Survey, 1999

Figure 2. Topography of the Upper Hudson River Basin in New York, and locations of wells sampled in 2007. 


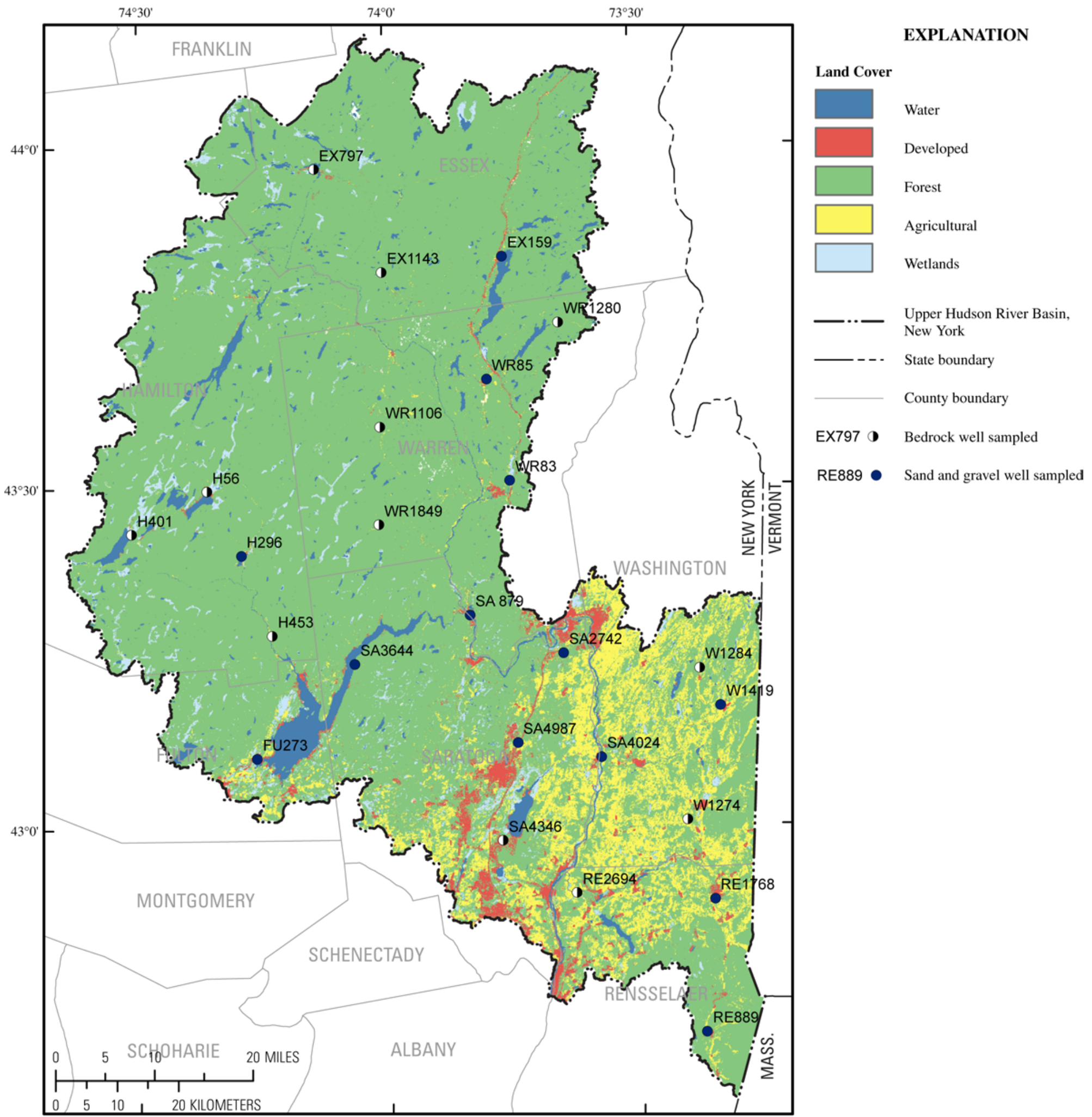

Base from U.S. Geological Survey digital data, 1983, 1:100,000 Universal Transverse Mercator projection

Land cover from Vogelmann and others, 2001 Zone 18

Figure 3. Land cover of the Upper Hudson River Basin in New York, and locations of wells sampled in 2007. 


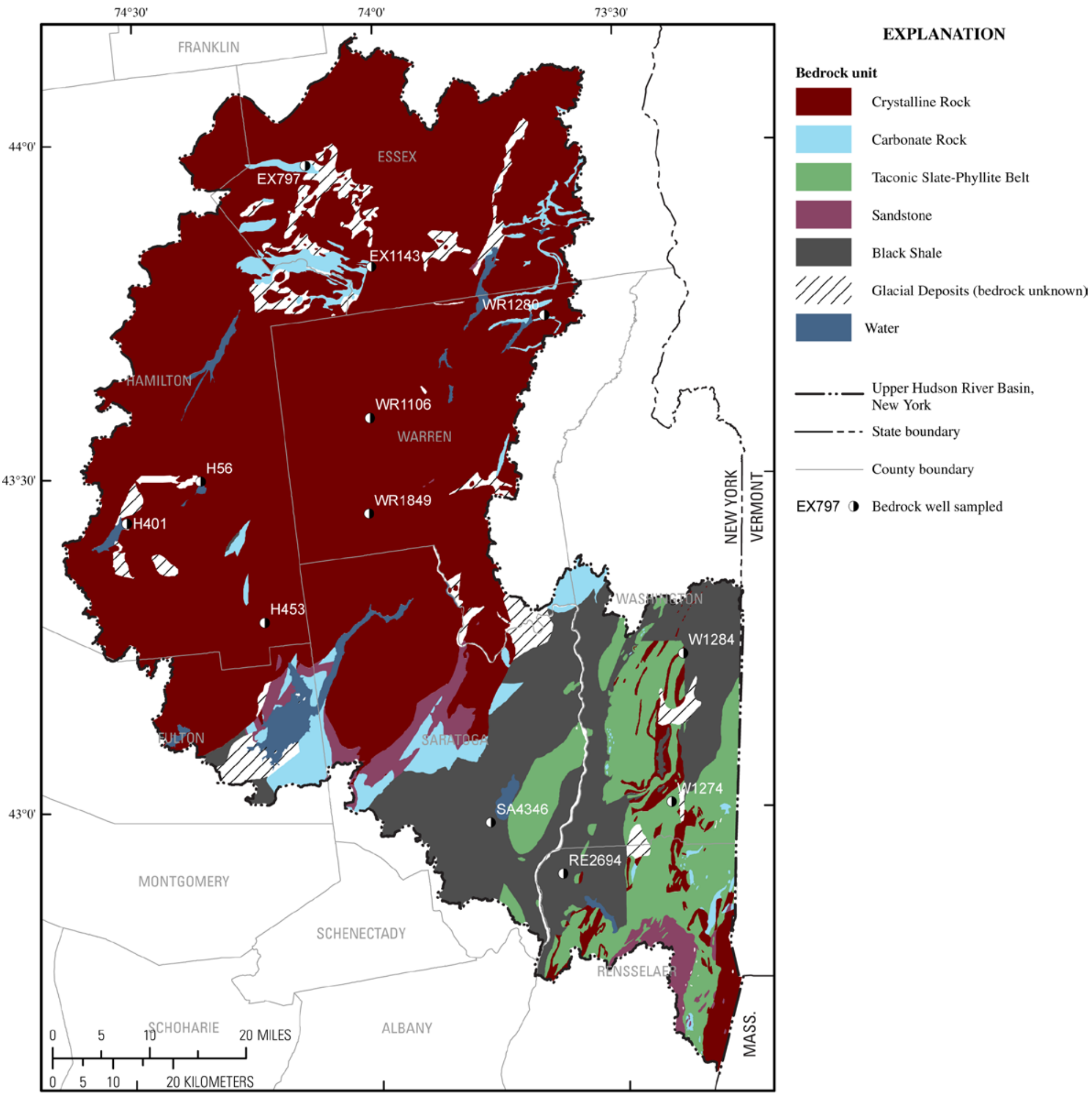

Base from U.S. Geological Survey digital data, 1983, 1:100,000 Universal Transverse Mercator projection

Geology modified from Fisher and others, 1970 Zone 18

Figure 4. Generalized bedrock geology of the Upper Hudson River Basin in New York, and locations of wells finished in bedrock sampled in 2007. 


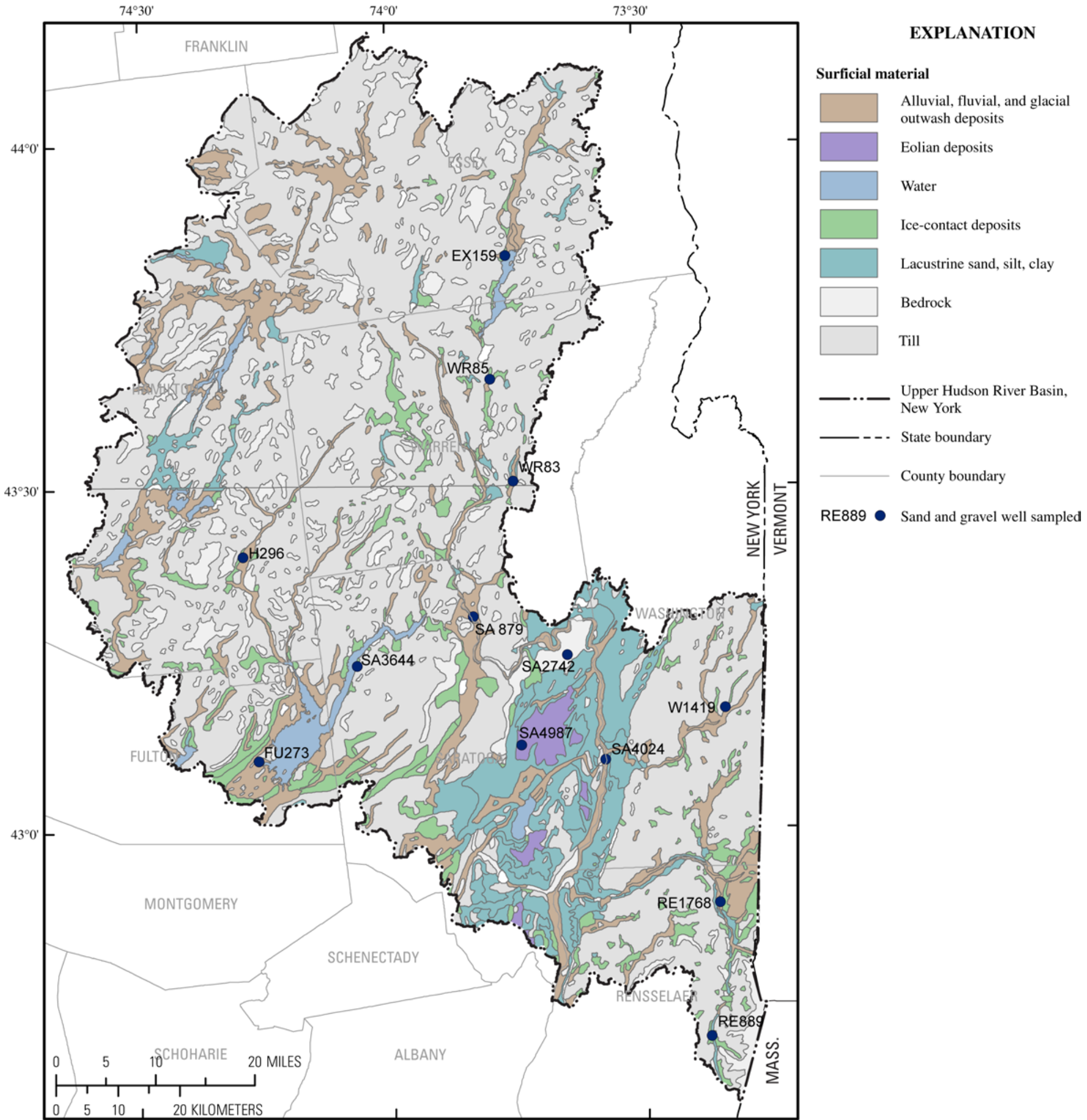

Base from U.S. Geological Survey digital data, 1983, 1:100,000 Universal Transverse Mercator projection

Geology modified from Cadwell, 1991 Zone 18

Figure 5. Generalized surficial geology of the Upper Hudson River Basin in New York, and locations of wells finished in sand and gravel deposits sampled in 2007. 
well, and follow-up phone calls were made to arrange a time for sampling. Well information such as depth was provided by water managers if a well-completion report for a specific well was unavailable. The aquifer type indicated for sampled wells was verified through inspection of published geologic maps including Fisher and others (1970) and Cadwell (1991).

Table 1. Information on wells from which water samples were collected in the Upper Hudson River Basin, New York, 2007.

[--, unknown; Prod., production well; Dom., domestic well; Devel. $\square$, developed; Forest $\square$, forested; Agric. $\square$, agricultural; Water $\square$, wetlands and open water. Well locations are shown in fig. 2.]

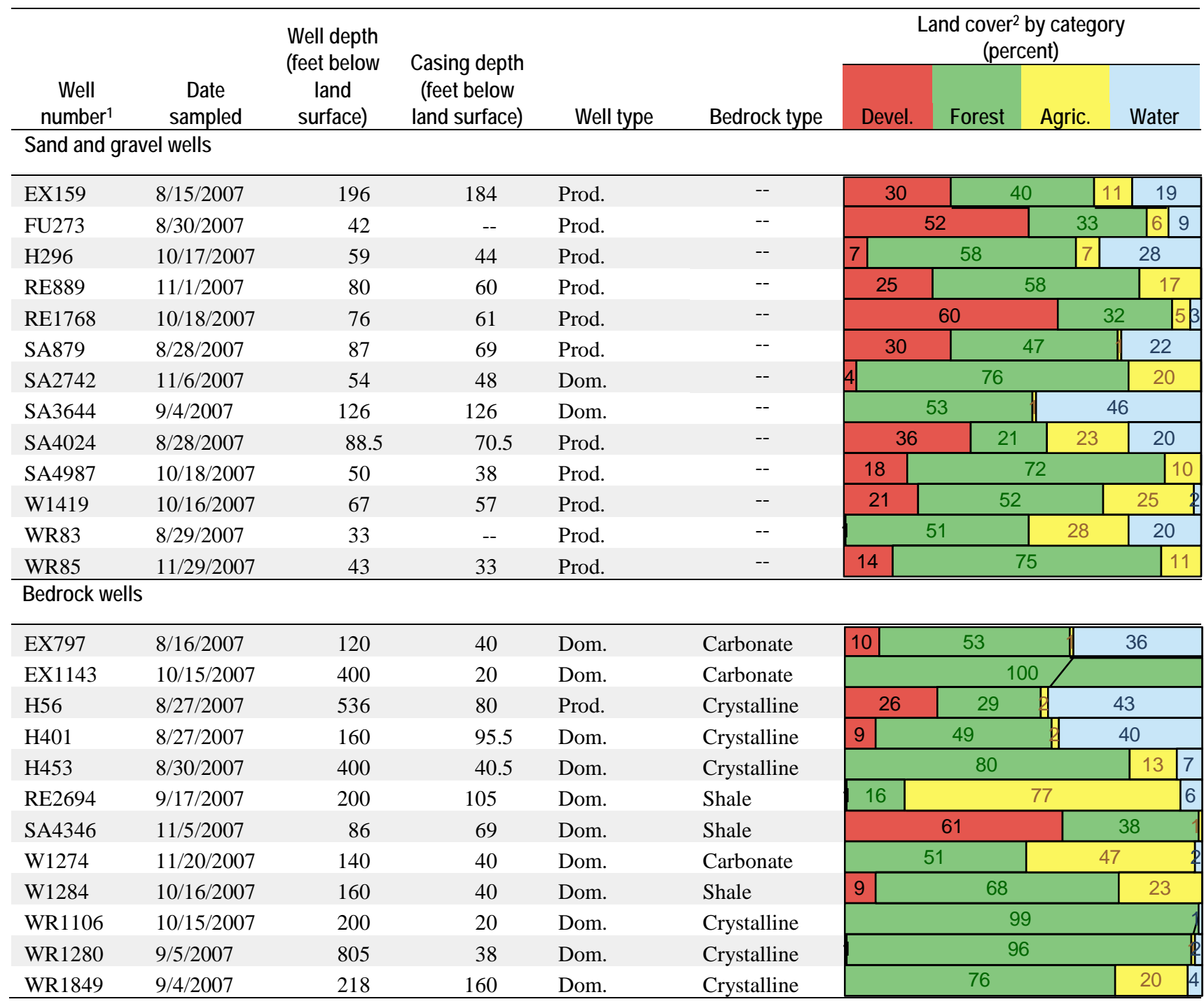

${ }^{1}$ EX, Essex County; FU, Fulton County; H, Hamilton County; RE, Rensselaer County; SA, Saratoga County; W, Washington County; WR, Warren County.

${ }^{2}$ Land cover, as percentage of area within a 0.5-mile radius of the well, interpreted from National Land Cover Data set, 1992. 
Table 2. Summary of information on wells from which water samples were collected in the Upper Hudson River Basin, New York, 2007.

[--, no wells]

\begin{tabular}{|c|c|c|c|c|}
\hline \multirow{2}{*}{\multicolumn{2}{|c|}{ Type of Well }} & \multicolumn{3}{|c|}{ Number of wells } \\
\hline & & Production & Domestic & Total \\
\hline Wells finished in sand and gravel & (33 to 196 feet deep) & 11 & 2 & 13 \\
\hline Wells finished in bedrock & (86 to 805 feet deep) & 1 & 11 & 12 \\
\hline Carbonate bedrock & & -- & 3 & 3 \\
\hline Shale bedrock & & -- & 3 & 3 \\
\hline Crystalline bedrock & & 1 & 5 & 6 \\
\hline Total number of wells & & 12 & 13 & 25 \\
\hline
\end{tabular}

\section{Sampling Methods}

The 25 wells were sampled from August through November 2007, and samples were collected and processed in accordance with documented USGS protocols (U.S. Geological Survey, variously dated). The samples were collected from a spigot between the well and the pressure tank, where possible, and before any water-treatment system, to be as representative of the aquifer water quality as possible. Most samples from domestic wells were collected from a spigot near the pressure tank; samples from production wells were collected at the spigot or faucet used for collection of raw-water samples by water managers.

One or two wells were sampled per day. Typically, samples were collected from one or more 10-ft lengths of Teflon tubing attached to a "garden-hose" type spigot located as close to the well as possible. Domestic wells were purged after the tubing was connected by running to waste for at least 20 minutes, or until at least one well-casing volume of water had passed the sampling point. Many of the production wells were pumped for at least 1 hour prior to sampling, typically at rates of about 100 $\mathrm{gal} / \mathrm{min}$. Domestic wells were purged at pumping rates ranging from about 2 to $5 \mathrm{gal} / \mathrm{min}$. Wells that had been used recently required removal of less than three well-casing volumes. During well purging, notes about the well and surrounding land and land use were taken, and a global positioning system (GPS) measurement of latitude and longitude was made. After the well was purged, field measurements of water temperature, $\mathrm{pH}$, specific conductance, and dissolved-oxygen concentration were recorded at regular intervals until these values had stabilized, after which the sample was collected (U.S. Geological Survey, variously dated).

The flow rate for sample collection was adjusted to less than $0.5 \mathrm{gal} / \mathrm{min}$. The Teflon sampling tube was connected to a sampling chamber constructed of a polyvinyl chloride (PVC) frame and a clear plastic chamber bag. The sampling chamber was placed on a plastic-box table with a built-in drain. Before each day of sampling, the Teflon tubing and spigot-attachment equipment were cleaned in the laboratory with a dilute phosphate-free detergent solution, followed by rinses with tap water and deionized water. Equipment for filtration of pesticide samples was rinsed with methanol. A new sampling-chamber bag was used at each site. Samples were collected and preserved in the sampling chamber according to standard USGS procedures. Sample bottles for nutrient, major-ion, and some trace-element analyses were filled with water filtered through disposable (one-time use) 0.45 - $\mu \mathrm{m}$-pore- 
size polyether sulfone capsule filters that were preconditioned in the laboratory with $1 \mathrm{~L}$ of deionized water the day of sample collection. Sample bottles for pesticide analyses were filled with water filtered through baked 0.7- $\mu$ m-pore-size glass fiber filters. Acid preservation was required for trace element, VOC, and some major-ion analyses. Acid preservative was added after the collection of other samples to avoid the possibility of cross contamination by the acid preservative; for example, samples preserved with nitric acid were acidified after the collection of samples for nutrient analysis. Bacterial samples were collected in accordance with NYSDEC and NYSDOH protocols, except that the tap from which each water sample was collected was not flame sterilized. Samples for radon analyses were collected through a septum chamber with a glass syringe according to standard USGS procedures. Water samples analyzed by NYSDOH-certified laboratories were collected in bottles provided by the analyzing laboratory. All samples except those for radiochemical analyses were chilled to $4^{\circ} \mathrm{C}$ or less after collection and shipped by overnight delivery to the designated laboratories.

Most sampling sites had easy access to a spigot; however, some production wells did not. Wells FU273, H56, H296, SA879, SA4024, and W1419 (fig. 2 and table 1) were sampled from taps or hydrants from which water-system personnel routinely collect raw-water samples. The syringe for radon-222 sample collection at these sites was inserted directly into the flowing water in the throat of the tap or hydrant to minimize sample exposure to the atmosphere.

\section{Analytical Methods}

Samples were analyzed for 225 physical properties and constituents, including inorganic constituents, nutrients, trace elements, radionuclides, pesticides and pesticide degradates, VOCs, and bacteria. Physical properties such as water temperature, $\mathrm{pH}$, dissolved oxygen concentration, and specific conductance were measured at the sampling site. Inorganic constituents, nutrients, trace elements, radon-222, pesticides and pesticide degradates, and VOCs were analyzed at the USGS NWQL in Denver, Colo.; additional pesticide and pesticide degradates were analyzed at the USGS OGRL in Lawrence, Kans. Total organic carbon and phenolic compounds were analyzed at H2M Labs in Melville, N.Y., and indicator bacteria were analyzed at St. Peter's Bender Laboratory in Albany, N.Y. Both of these laboratories are certified by NYSDOH.

Anion concentrations were measured by ion-exchange chromatography, and cation concentrations were measured by inductively coupled plasma-atomic emission spectrometry (ICP-AES), as described in Fishman (1993). Nutrients were analyzed by colorimetry, as described by Fishman (1993), and Kjeldahl digestion with photometric finish, as described by Patton and Truitt (2000). Mercury concentrations were measured through cold vapor-atomic fluorescence spectrometry according to methods described by Garbarino and Damrau (2001). Arsenic, chromium, and nickel analyses used collision/reaction cell inductively coupled plasma-mass spectrometry (cICPMS) as described by Garbarino and others (2006). The remaining trace elements were analyzed by ICP-AES (Struzeski and others, 1996), inductively coupled plasma-optical emission spectrometry (ICP-OES), and inductively coupled plasma-mass spectrometry (ICP-MS) (Garbarino and Struzeski, 1998). In-bottle digestions for trace-element analyses described by Hoffman and others (1996) were followed. Radon-222 was measured through liquid-scintillation counting (ASTM International, 2006).

Samples for pesticide analyses were processed as described by Wilde and others (2004). Pesticides and pesticide-degradates were analyzed at the NWQL through gas chromatography-mass spectrometry (GC-MS) and high-performance liquid chromatography-mass spectrometry (HPLC-MS), as described by Zaugg and others (1995), Sandstrom and others (2001), and Furlong and others (2001). Acetamide parent compounds and degradation-product analyses were done by liquid chromatography- 
mass spectrometry (LC-MS) at the USGS-OGRL according to methods described by Lee and Strahan (2003). VOSs were analyzed by GC-MS using methods described by Connor and others (1998).

Concentrations of total organic carbon were measured by method SW-846 9060 (U.S. Environmental Protection Agency, 2004), and total phenolic compounds were analyzed by USEPA method 420.2 (U.S. Environmental Protection Agency, 1983). Indicator bacteria samples were tested for total coliform, fecal coliform, and Escherichia coli (E. coli) through Standard Method 9222 (American Public Health Association, 2005). A heterotrophic plate count test (SM 9215 B) also was done.

In addition to the 25 groundwater samples, one blank sample and two sequential replicate samples were collected for quality assurance. Nitrogen-purged VOC/pesticide-grade blank water and inorganic-grade blank water supplied by the USGS-NWQL were used for a laboratory equipment blank before environmental-sample collection began. The water for unfiltered constituents was run through a piece of the Teflon tubing used for sampling; water for filtered-water constituents was pumped through the Teflon tubing into cleaned, preconditioned filters. Samples were acidified in the same manner as environmental well-water samples. The only constituent that exceeded laboratory reporting levels (LRLs) in the blank was sample color, which was measured at 2 platinum-cobalt units. The differences from the sequential replicate samples were less than 5 percent for all constituents detected above the LRL in the replicate samples except for color, zinc, and heterotrophic plate count, which were detected in one replicate sample at levels close to the LRL, where small differences in concentration make large relative percent-concentration differences.

\section{Groundwater Quality}

The 25 samples were analyzed for 225 constituents and physical properties. Fewer than half (156) of these were detected above the LRLs in any sample (appendix table A1). Results for the remaining 69 constituents and properties that were detected are presented in the appendix (tables A2 through A8). Some concentrations were reported as "estimated." Estimated concentrations are typically reported where the detected value is less than the established LRL, or when recovery of a compound has been shown to be highly variable (Childress and others, 1999). Concentrations of some constituents exceeded maximum contaminant levels (MCLs) or secondary drinking-water standards (SDWS) set by the USEPA (U.S. Environmental Protection Agency, 2003) or NYSDOH (New York State Department of Health, 2007). MCLs are enforceable standards for finished water at public water supplies; they are not enforceable for private homeowner wells but are presented here as a standard for evaluation of the water-quality results. SDWS are nonenforceable drinking-water standards that typically relate to esthetic concerns such as taste, odor, or staining of plumbing fixtures.

\section{Physical Properties}

The color of samples ranged from less than $(<) 1$ to 35 Pt-Co units; the median sample color was 5 Pt-Co units (appendix table A2). The color of one sample, 35 Pt-Co units, exceeded the NYSDOH MCL and USEPA SDWS of 15 Pt-Co units. Dissolved oxygen concentration ranged from < 0.1 to 10.3 $\mathrm{mg} / \mathrm{L}$ and was generally greater in samples from sand and gravel wells (median $5.4 \mathrm{mg} / \mathrm{L}$ ) than in samples from bedrock wells (median $0.4 \mathrm{mg} / \mathrm{L}$ ). Sample $\mathrm{pH}$ was typically near neutral or slightly basic (median 7.6 in all wells) and ranged from 6.5 to 9.3; the median $\mathrm{pH}$ was 7.0 in samples from sand and gravel wells and 7.8 in samples from bedrock wells. The $\mathrm{pH}$ of two samples (8.8 and 9.3) exceeded the USEPA SDWS range for $\mathrm{pH}$ (6.5 to 8.5); both samples were from bedrock wells. Specific conductance ranged from 58 to $1,100 \mu \mathrm{S} / \mathrm{cm}$ at $25^{\circ} \mathrm{C}$ and tended to be higher in samples from wells finished in sand 
and gravel (median $550 \mu \mathrm{S} / \mathrm{cm}$ at $25^{\circ} \mathrm{C}$ ) than in samples from bedrock wells (median $287 \mu \mathrm{S} / \mathrm{cm}$ at $25^{\circ} \mathrm{C}$ ). Water temperature ranged from 7.6 to $13.5^{\circ} \mathrm{C}$; the median temperature was $9.7^{\circ} \mathrm{C}$.

\section{Major lons}

The anion with the highest concentrations was bicarbonate (table 3 and appendix table A3); the median concentration was $123 \mathrm{mg} / \mathrm{L}$. The cation with the greatest median concentration $(33.9 \mathrm{mg} / \mathrm{L})$ was calcium. The concentration of sodium in five samples exceeded the USEPA nonregulatory drinking-water advisory taste threshold of $60 \mathrm{mg} / \mathrm{L}$; the maximum concentration of sodium was 105 $\mathrm{mg} / \mathrm{L}$. The concentration of chloride was generally higher in samples from wells finished in sand and gravel (median $73.2 \mathrm{mg} / \mathrm{L}$ ) than in bedrock (median $3.52 \mathrm{mg} / \mathrm{L}$ ) (table 3). The concentration of fluoride in samples from bedrock wells (median $0.32 \mathrm{mg} / \mathrm{L}$ ) was generally higher than in samples from sand and gravel wells (median $<0.12 \mathrm{mg} / \mathrm{L}$ ). Concentrations of chloride, fluoride, and sulfate did not exceed established MCLs in any sample.

Table 3. Drinking-water standards and summary statistics for concentrations of major ions in groundwater samples from the Upper Hudson River Basin, New York, 2007.

[All concentrations are in milligrams per liter in filtered water; --, not applicable; <, less than]

\begin{tabular}{|c|c|c|c|c|c|c|c|c|c|c|}
\hline & \multirow[b]{3}{*}{ Constituent } & \multicolumn{9}{|c|}{ Summary statistics and concentrations } \\
\hline & & \multirow{2}{*}{$\begin{array}{l}\text { Drinking- } \\
\text { water } \\
\text { standard }\end{array}$} & \multirow{2}{*}{$\begin{array}{l}\text { Number of } \\
\text { samples } \\
\text { exceeding } \\
\text { standard }\end{array}$} & \multirow{2}{*}{$\begin{array}{l}\text { Median (all } \\
\text { samples) }\end{array}$} & \multicolumn{3}{|c|}{$\begin{array}{c}\text { Sand and gravel aquifers } \\
\text { (13 samples) }\end{array}$} & \multicolumn{3}{|c|}{$\begin{array}{c}\text { Bedrock aquifers } \\
\text { (12 samples) }\end{array}$} \\
\hline & & & & & Min & Median & $\operatorname{Max}$ & Min & Median & $\operatorname{Max}$ \\
\hline \multirow{4}{*}{ : } & Calcium & -- & -- & 33.9 & 6.27 & 44.0 & 105 & 2.52 & 28.0 & 75 \\
\hline & Magnesium & -- & -- & 6.93 & 1.60 & 7.02 & 25.8 & 1.22 & 4.19 & 12.2 \\
\hline & Potassium & -- & -- & .98 & .44 & 1.47 & 3.27 & .49 & .84 & 14.7 \\
\hline & Sodium & $60^{\mathrm{a}}$ & 5 & 12.4 & 1.77 & 34.3 & 105 & 1.31 & 5.64 & 87.7 \\
\hline \multirow{4}{*}{ 告 } & Bicarbonate & -- & -- & 123 & 26 & 118 & 264 & 61 & 129 & 261 \\
\hline & Chloride & $250^{\mathrm{bc}}$ & 0 & 14.1 & 1.05 & 73.2 & 215 & .39 & 3.52 & 29.7 \\
\hline & Fluoride & $\begin{array}{l}2.2^{\mathrm{b}} \\
2.0^{\mathrm{c}}\end{array}$ & 0 & .07 & $<.10$ & $<.12$ & .07 & .06 & .32 & 1.36 \\
\hline & Sulfate & $250^{\mathrm{bc}}$ & 0 & 10.4 & 5.04 & 13.0 & 23.9 & $<.18$ & 8.42 & 82.3 \\
\hline \multicolumn{4}{|c|}{ Hardness, $\mathrm{mg} / \mathrm{L}$ as $\mathrm{CaCO}_{3}$} & 110 & 22 & 140 & 360 & 11 & 92 & 240 \\
\hline \multicolumn{4}{|c|}{ Alkalinity, mg/L as $\mathrm{CaCO}_{3}$} & 101 & 21 & 97 & 216 & 50 & 106 & 216 \\
\hline \multicolumn{4}{|c|}{ Residue on evaporation, mg/L } & 217 & 39 & 317 & 609 & 80 & 180 & 338 \\
\hline
\end{tabular}

${ }^{\text {a }}$ U.S. Environmental Protection Agency Drinking Water Advisory Taste Threshold

b New York State Department of Health Maximum Contaminant Level

c U.S. Environmental Protection Agency Secondary Drinking Water Standard

Water hardness in the basin ranged from 11 to $360 \mathrm{mg} / \mathrm{L}$ as $\mathrm{CaCO}_{3}$, and 15 of 25 samples were soft to moderately hard (120 mg/L as $\mathrm{CaCO}_{3}$ or less; Hem, 1985); the median hardness was $110 \mathrm{mg} / \mathrm{L}$ as $\mathrm{CaCO}_{3}$. Concentrations of calcium and magnesium, and therefore water hardness, were generally greater in samples from wells finished in sand and gravel than in samples from wells finished in 
bedrock. The three bedrock wells finished in carbonate rock produced hard water (121 to $180 \mathrm{mg} / \mathrm{L}$ as $\mathrm{CaCO}_{3}$ ) or very hard water (more than $180 \mathrm{mg} / \mathrm{L}$ as $\mathrm{CaCO}_{3}$ ). Alkalinity ranged from 21 to $216 \mathrm{mg} / \mathrm{L}$ as $\mathrm{CaCO}_{3}$; the median was $101 \mathrm{mg} / \mathrm{L}$ of $\mathrm{CaCO}_{3}$. Residue on evaporation at $180^{\circ} \mathrm{C}$, a measurement of total dissolved solids, ranged from 39 to $609 \mathrm{mg} / \mathrm{L}$ and the median was $217 \mathrm{mg} / \mathrm{L}$.

\section{Nutrients and Organic Carbon}

The concentrations of ammonia ranged from $<0.020$ to $0.505 \mathrm{mg} / \mathrm{L}$ as nitrogen $(\mathrm{N})$.

Concentrations of nitrate plus nitrite were generally higher in samples from sand and gravel wells than in samples from bedrock wells (table 4). Concentrations of nitrate plus nitrite ranged from $<0.04$ to $13.1 \mathrm{mg} / \mathrm{L}$ as $\mathrm{N}$ (table 4 and appendix table A4); the median concentration was $0.47 \mathrm{mg} / \mathrm{L}$ as $\mathrm{N}$ in samples from sand and gravel wells and $0.05 \mathrm{mg} / \mathrm{L}$ as $\mathrm{N}$ (estimated) in samples from bedrock wells. Nitrite was detected in fewer than-one third of the samples and had a maximum concentration of 0.064 $\mathrm{mg} / \mathrm{L}$ as $\mathrm{N}$. The concentration of nitrate plus nitrite exceeded the USEPA and NYSDOH MCL of 10 $\mathrm{mg} / \mathrm{L}$ as $\mathrm{N}$ in two samples (11.1 and $13.1 \mathrm{mg} / \mathrm{L}$ as $\mathrm{N}$ ). The concentration of nitrite did not exceed the MCL ( $1 \mathrm{mg} / \mathrm{L}$ as $\mathrm{N}$ ) in any sample. Orthophosphate concentrations ranged from 0.003 (estimated) to $0.146 \mathrm{mg} / \mathrm{L}$ as phosphorus (P). Organic carbon was detected in 10 samples, and the maximum concentration was $2.8 \mathrm{mg} / \mathrm{L}$.

Table 4. Drinking-water standards and summary statistics for concentrations of nutrients in groundwater samples from the Upper Hudson River Basin, New York, 2007.

[All concentrations in milligrams per liter in filtered water except as noted. N, nitrogen; P, phosphorus; --, not applicable; <, less than; E, estimated.]

\begin{tabular}{|c|c|c|c|c|c|c|c|c|c|}
\hline \multicolumn{10}{|c|}{ Summary statistics and concentrations } \\
\hline \multirow[t]{2}{*}{ Constituent } & \multirow{2}{*}{$\begin{array}{l}\text { Drinking- } \\
\text { water } \\
\text { standard }\end{array}$} & \multirow{2}{*}{$\begin{array}{l}\text { Number of } \\
\text { samples } \\
\text { exceeding } \\
\text { standard }\end{array}$} & \multirow{2}{*}{$\begin{array}{c}\text { Median } \\
\text { (all } \\
\text { samples) }\end{array}$} & \multicolumn{3}{|c|}{$\begin{array}{l}\text { Sand and gravel aquifers } \\
\text { (13 samples) }\end{array}$} & \multicolumn{3}{|c|}{$\begin{array}{l}\text { Bedrock aquifers } \\
\text { (12 samples) }\end{array}$} \\
\hline & & & & Minimum & Median & Maximum & Minimum & Median & Maximum \\
\hline Ammonia plus organic $\mathrm{N}$, as $\mathrm{N}$ & -- & -- & $<0.14$ & $<0.10$ & $<0.14$ & 0.21 & $<0.10$ & $<0.14$ & .55 \\
\hline Ammonia, as $\mathrm{N}$ & -- & -- & $<.020$ & $<.020$ & $<.020$ & .138 & $<.020$ & E .014 & .505 \\
\hline Nitrite plus nitrate, as $\mathrm{N}$ & $10^{\mathrm{ab}}$ & 2 & .22 & E .03 & .47 & 11.1 & $<.04$ & E.05 & 13.1 \\
\hline Nitrite, as $\mathrm{N}$ & $1^{\mathrm{ab}}$ & 0 & $<.002$ & $<.002$ & $<.002$ & .064 & $<.002$ & $<.002$ & .005 \\
\hline Orthophosphate, as P & -- & -- & .008 & E.003 & .008 & .018 & E.004 & .011 & .146 \\
\hline Total organic carbon, unfiltered & -- & -- & $<1.0$ & $<1.0$ & $<1.0$ & 1.9 & $<1.0$ & $<1.0$ & 2.8 \\
\hline
\end{tabular}

a U.S. Environmental Protection Agency Maximum Contaminant Level.

b New York State Department of Health Maximum Contaminant Level.

\section{Trace Elements and Radionuclides}

The trace elements present in the highest median concentrations in the samples were strontium (median $217 \mu \mathrm{g} / \mathrm{L}$ ), iron (median $39 \mu \mathrm{g} / \mathrm{L}$ in unfiltered water; $12 \mu \mathrm{g} / \mathrm{L}$ in filtered water), boron (median $14 \mu \mathrm{g} / \mathrm{L}$ ), and barium (median $10.3 \mu \mathrm{g} / \mathrm{L}$ ) (table 5 and appendix table A5). Median concentrations of aluminum and molybdenum were greater in samples from bedrock wells than in samples from sand and 
gravel wells (table 5). The concentration of aluminum in three samples exceeded the USEPA SDWS range of 50 to $200 \mu \mathrm{g} / \mathrm{L}$. The concentration of iron in one unfiltered sample exceeded the USEPA SDWS and NYSDOH MCL for iron of $300 \mu \mathrm{g} / \mathrm{L}$. The concentration of manganese in seven unfiltered and six filtered samples exceeded the USEPA SDWS of $50 \mu \mathrm{g} / \mathrm{L}$; the concentration in two filtered and three unfiltered samples exceeded the NYSDOH MCL of $300 \mu \mathrm{g} / \mathrm{L}$. Drinking-water standards for antimony, arsenic, barium, beryllium, cadmium, chromium, copper, lead, mercury, selenium, silver, thallium, zinc, and uranium were not exceeded; mercury and silver were not detected in any sample (appendix table A1).

Radon-222 activities in the water samples ranged from 20 (the LRL) to 2,930 pCi/L, and the median was $280 \mathrm{pCi} / \mathrm{L}$. The highest radon activities (greater than $(>$ ) 1,000 pCi/L) were in samples from bedrock wells. Radon is currently not regulated in drinking water; however, the USEPA has proposed a two-part standard for radon in drinking water: (1) a $300 \mathrm{pCi} / \mathrm{L} \mathrm{MCL}$ for areas that do not implement an indoor air-radon mitigation program, and (2) an alternative MCL (AMCL) of 4,000 pCi/L for areas that do (U.S. Environmental Protection Agency, 1999). Activities in 11 (44 percent) of the samples exceeded the proposed MCL; none of the samples exceeded the proposed AMCL.

\section{Pesticides}

Ten pesticides were detected in 11 samples. Most of the pesticides detected were broadleaf herbicides or their degradates; an insecticide (fipronil) and a fungicide (metalaxyl) were also detected (appendix table A6). Pesticides were detected in eight samples from sand and gravel wells and in three samples from bedrock wells. Most detections were in hundredths or thousandths of micrograms per liter; the constituents with the highest concentrations were metolachlor degradates (maximum 1.47 $\mu \mathrm{g} / \mathrm{L}$ ). The most frequently detected pesticides were alachlor ethanesulfonic acid (ESA) (six samples), metolachlor ESA (four samples), metolachlor OA (oxanilic acid) (three samples), and CIAT (2-chloro4-isopropylamino-6-amino-s-triazine) (three samples). No pesticide concentrations exceeded established drinking-water standards. Pesticide degradates are not currently regulated.

\section{Volatile Organic Compounds and Phenolic Compounds}

VOCs were detected in samples from 10 wells -8 finished in sand and gravel and 2 finished in bedrock (appendix table A7). Six VOCs were detected-three trihalomethanes (THMs), methyl tertbutyl ether (MTBE), tetrachloroethene, and toluene. THMs are byproducts that form when chlorine or bromine are used as disinfectants; THMs are also used as solvents. The THMs detected were bromodichloromethane, dibromochloromethane, and trichloromethane (chloroform). Bromodichloromethane was detected in three samples and had a maximum concentration of $0.3 \mu \mathrm{g} / \mathrm{L}$; dibromochloromethane was detected in one sample at a concentration of $0.2 \mu \mathrm{g} / \mathrm{L}$; and trichloromethane was detected in eight samples and had a maximum concentration of $1.0 \mu \mathrm{g} / \mathrm{L}$. The USEPA and NYSDOH MCL for total trihalomethanes (TTHMs) is $80 \mu \mathrm{g} / \mathrm{L}$; the maximum TTHMs in the samples was $1 \mu \mathrm{g} / \mathrm{L}$ (trichloromethane). MTBE, a gasoline additive, was detected in three samples; the maximum concentration $(4.2 \mu \mathrm{g} / \mathrm{L})$ was in a sample from a bedrock well. Tetrachloroethene (PERC), a solvent sometimes used for dry cleaning, was detected in one well at a concentration of $0.3 \mu \mathrm{g} / \mathrm{L}$; the USEPA and NYSDOH MCL for tetrachloroethene is $5 \mu \mathrm{g} / \mathrm{L}$. Toluene, a component of gasoline, was detected in one well at a concentration of $1.1 \mu \mathrm{g} / \mathrm{L}$; the NYSDOH MCL for toluene is $5 \mu \mathrm{g} / \mathrm{L}$, and the USEPA MCL is $1,000 \mu \mathrm{g} / \mathrm{L}$. Phenolic compounds were detected in one sample, which was from a bedrock well, at a concentration of $5.1 \mu \mathrm{g} / \mathrm{L}$. 
Table 5. Drinking-water standards and summary statistics for concentrations of trace elements and radionuclides in groundwater samples from the Upper Hudson River Basin, New York, 2007.

[ $\mu \mathrm{g} / \mathrm{L}$, micrograms per liter; <, less than; E, estimated value; --, not applicable; $\mathrm{pCi} / \mathrm{L}$, picocuries per liter]

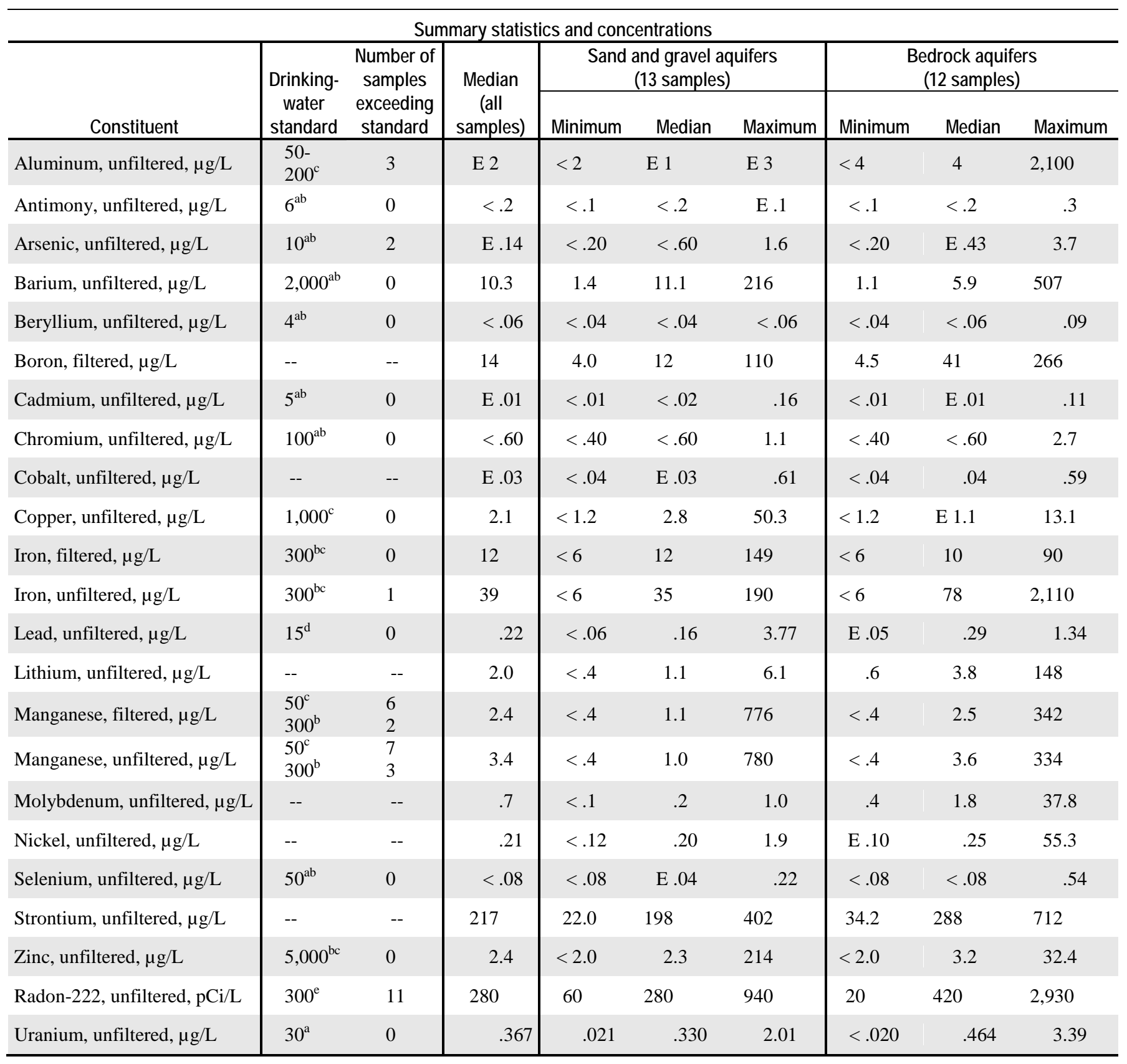

${ }^{\text {a }}$ U.S. Environmental Protection Agency Maximum Contaminant Level.

${ }^{\mathrm{b}}$ New York State Department of Health Maximum Contaminant Level.

${ }^{c}$ U.S. Environmental Protection Agency Secondary Drinking Water Standard.

${ }^{d}$ U.S. Environmental Protection Agency Treatment Technique.

e U.S. Environmental Protection Agency Proposed Maximum Contaminant Level.

${ }^{\mathrm{f}}$ Constituent detected but not quantified. 


\section{Pesticides}

Ten pesticides were detected in 11 samples. Most of the pesticides detected were broadleaf herbicides or their degradates; an insecticide (fipronil) and a fungicide (metalaxyl) were also detected (appendix table A6). Pesticides were detected in eight samples from sand and gravel wells and in three samples from bedrock wells. Most detections were in hundredths or thousandths of micrograms per liter; the constituents with the highest concentrations were metolachlor degradates (maximum 1.47 $\mu \mathrm{g} / \mathrm{L}$ ). The most frequently detected pesticides were alachlor ethanesulfonic acid (ESA) (six samples), metolachlor ESA (four samples), metolachlor OA (oxanilic acid) (three samples), and CIAT (2-chloro4-isopropylamino-6-amino-s-triazine) (three samples). No pesticide concentrations exceeded established drinking-water standards. Pesticide degradates are not currently regulated.

\section{Volatile Organic Compounds and Phenolic Compounds}

VOCs were detected in samples from 10 wells - 8 finished in sand and gravel and 2 finished in bedrock (appendix table A7). Six VOCs were detected-three trihalomethanes (THMs), methyl tertbutyl ether (MTBE), tetrachloroethene, and toluene. THMs are byproducts that form when chlorine or bromine are used as disinfectants; THMs are also used as solvents. The THMs detected were bromodichloromethane, dibromochloromethane, and trichloromethane (chloroform). Bromodichloromethane was detected in three samples and had a maximum concentration of $0.3 \mu \mathrm{g} / \mathrm{L}$; dibromochloromethane was detected in one sample at a concentration of $0.2 \mu \mathrm{g} / \mathrm{L}$; and trichloromethane was detected in eight samples and had a maximum concentration of $1.0 \mu \mathrm{g} / \mathrm{L}$. The USEPA and NYSDOH MCL for total trihalomethanes (TTHMs) is $80 \mu \mathrm{g} / \mathrm{L}$; the maximum TTHMs in the samples was $1 \mu \mathrm{g} / \mathrm{L}$ (trichloromethane). MTBE, a gasoline additive, was detected in three samples; the maximum concentration $(4.2 \mu \mathrm{g} / \mathrm{L})$ was in a sample from a bedrock well. Tetrachloroethene (PERC), a solvent sometimes used for dry cleaning, was detected in one well at a concentration of $0.3 \mu \mathrm{g} / \mathrm{L}$; the USEPA and NYSDOH MCL for tetrachloroethene is $5 \mu \mathrm{g} / \mathrm{L}$. Toluene, a component of gasoline, was detected in one well at a concentration of $1.1 \mu \mathrm{g} / \mathrm{L}$; the NYSDOH MCL for toluene is $5 \mu \mathrm{g} / \mathrm{L}$, and the USEPA MCL is $1,000 \mu \mathrm{g} / \mathrm{L}$. Phenolic compounds were detected in one sample, which was from a bedrock well, at a concentration of $5.1 \mu \mathrm{g} / \mathrm{L}$.

\section{Bacteria}

Total coliform bacteria were detected in one sample from a bedrock well (appendix table A8). The NYSDOH and USEPA MCL for total coliform bacteria is exceeded when 5 percent of samples of finished water collected in 1 month test positive for total coliform (if 40 or more samples are collected per month) or when two samples are positive for total coliform (if fewer than 40 samples are collected per month). The owner of the well was notified of the detection upon receipt of the results from the laboratory. Fecal coliform and E. coli were not detected in any sample. The heterotrophic plate count ranged from $<1$ colony-forming unit (CFU) per $\mathrm{mL}$ to $252 \mathrm{CFU} / \mathrm{mL}$. The USEPA MCL for the heterotrophic plate count is $500 \mathrm{CFU} / \mathrm{mL}$; this limit was not exceeded in any sample.

\section{Summary}

Groundwater samples were collected from August through November 2007 from 13 wells finished in sand and gravel and 12 wells finished in bedrock to characterize the groundwater quality in the Upper Hudson River Basin in New York State. The wells finished in sand and gravel ranged from 33 to $196 \mathrm{ft}$ deep; those finished in bedrock ranged from 86 to $805 \mathrm{ft}$ deep and were typically finished in crystalline rock. Twelve of the 25 wells sampled were production wells, and 13 were domestic wells. 
Sample collection and analyses followed standard USGS procedures and other documented procedures. Samples were analyzed for physical properties and for concentrations of major ions, nutrients, trace elements, radon-222, pesticides, VOCs, and bacteria. Many of the 225 constituents were not detected in any of the samples.

The samples generally indicated good water quality, although concentrations of some constituents — color, $\mathrm{pH}$, sodium, nitrate, aluminum, iron, manganese, radon-222, and bacteriaexceeded primary, secondary, or proposed drinking-water standards.. The constituents most frequently detected in concentrations exceeding drinking-water standards were radon-222 (11 samples with concentrations greater than the USEPA proposed MCL of $300 \mathrm{pCi} / \mathrm{L}$ ), manganese (7 unfiltered samples with concentrations greater than the USEPA SDWS of $50 \mu \mathrm{g} / \mathrm{L}$ ), and sodium (5 samples with concentrations greater than the USEPA drinking-water advisory taste threshold of $60 \mathrm{mg} / \mathrm{L}$ ). Two samples had concentrations of nitrate plus nitrite that exceeded the USEPA and NYSDOH MCL of 10 $\mathrm{mg} / \mathrm{L}$ as N. No pesticide or VOC was detected above established drinking-water standards.

The water generally ranged from soft to moderately hard. Some constituents, notably dissolved oxygen and nitrate plus nitrite, were detected more frequently in samples from sand and gravel wells than in samples from bedrock wells. The highest radon-222 activities were in samples from bedrock wells (maximum 2,930 pCi/L). Ten pesticides and pesticide degradates were detected in eight samples from sand and gravel wells and in three samples from bedrock wells; most were trace-level detections of broadleaf herbicides or their degradates. Most VOC detections were in samples from sand and gravel wells; these included three trihalomethanes plus MTBE, toluene, and tetrachloroethene. No VOC concentrations exceeded drinking-water standards.

\section{References Cited}

American Public Health Association, 2005, Standard methods for the examination of water and wastewater (21st ed.): Washington, D.C., American Public Health Association, American Water Works Association, and Water Environment Federation [variously paged].

ASTM International, 2006, D5072-98(2006), Standard test method for radon in drinking water: ASTM International, accessed December 28, 2006, at http://www.astm.org

Butch, G.K., Murray, P.M., Hebert, G.J., and Weigel, J.F., 2003, Water Resources Data, New York, Water Year 2002: U.S. Geological Survey Water-Data Report, NY-02-1, p. 502-520.

Cadwell, D.H., 1991, Surficial geologic map of New York: New York State Museum Map and Chart Series no. 40, Adirondack sheet, scale 1:250,000.

Childress, C.J.O., Foreman, W.T., Connor, B.F., and Maloney, T.J., 1999, New reporting procedures based on long-term method detection levels and some considerations for interpretations of waterquality data provided by the U.S. Geological Survey National Water Quality Laboratory: U.S. Geological Survey Open-File Report 99-193, 19 p.

Connor, B.F., Rose, D.L., Noriega, M.C., Murtagh, L.K., and Abney, S.R., 1998, Methods of analysis by the U.S. Geological Survey National Water Quality Laboratory-Determination of 86 volatile organic compounds in water by gas chromatography/mass spectrometry, including detections less than reporting limits: U.S. Geological Survey Open-File Report 97-829, 78 p. 
Eckhardt, D.A., Reddy, J.E., and Tamulonis, K.L., 2007, Ground-water quality in the Genesee River Basin, New York, 2005-06: U.S. Geological Survey Open-File Report 2007-1093, 26 p., online only at $h t t p: / / p u b s . u s g s . g o v / o f / 2007 / 1093 /$.

Eckhardt, D.A., Reddy, J.E., and Tamulonis, K.L., 2008, Ground-water quality in western New York, 2006: U.S. Geological Survey Open-File Report 2008-1140, 36 p., online only at http://pubs.usgs.gov/of/2008/1140/.

Fisher, D.W., Isachsen, Y.W., and Rickard, L.V., 1970, Geologic map of New York State: New York State Museum Map and Chart Series no. 15, Adirondack sheet, scale 1:250,000.

Fishman, M.J., ed., 1993, Methods of analysis by the U.S. Geological Survey National Water Quality Laboratory-Determination of inorganic and organic constituents in water and fluvial sediments: U.S. Geological Survey Open-File Report 93-125, 217 p.

Furlong, E.T., Anderson, B.D., Werner, S.L., Soliven, P.P., Coffey, L.J., and Burkhardt, M.R., 2001, Methods of analysis by the U.S. Geological Survey National Water Quality LaboratoryDetermination of pesticides in water by graphitized carbon-based solid-phase extraction and highperformance liquid chromatography/mass spectrometry: U.S. Geological Survey Water-Resources Investigation Report 01-4134, 73 p.

Garbarino, J.R., and Damrau, D.L., 2001, Methods of analysis by the U.S. Geological Survey National Water Quality Laboratory-Determination of organic plus inorganic mercury in filtered and unfiltered natural water with cold vapor-atomic fluorescence spectrometry: U.S. Geological Survey WaterResources Investigation Report 01-4132, 16 p.

Garbarino, J.R., Kanagy, L.K., and Cree, M.E., 2006, Determination of elements in natural-water, biota, sediment and soil samples using collision/reaction cell inductively coupled plasma-mass spectrometry: U.S. Geological Survey Techniques and Methods, book 5, sec. B, chap.1, 88 p.

Garbarino, J.R., and Struzeski, T.M., 1998, Methods of analysis by the U.S. Geological Survey National Water Quality Laboratory-Determination of elements in whole-water digests using inductively coupled plasma-optical emission spectrometry and inductively coupled plasma-mass spectrometry: U.S. Geological Survey Open-File Report 98-165, 101 p.

Hammond, D.S., Heath, R.C., and Waller, R.M., 1978, Ground-water data on the Hudson River Basin, New York: U.S. Geological Survey Open-File Report 78-710, 18 p.

Hem, J.D., 1985, Study and interpretation of the chemical characteristics of natural water: U.S. Geological Survey Water-Supply Paper 2254, 264 p.

Hetcher-Aguila, K.K., 2005, Ground-water quality in the Chemung River Basin, New York, 2003: U.S. Geological Survey Open-File Report 2004-1329, 19 p., online only at http://ny.water.usgs.gov/pubs/of/of041329/. 
Hetcher-Aguila, K.K., and Eckhardt, D.A., 2006, Ground-water quality in the upper Susquehanna River Basin, New York, 2004: U.S. Geological Survey Open-File Report 2006-1161, 21 p., online only at http://pubs.usgs.gov/of/2006/1161/.

Hoffman, G.L., Fishman, M.J., and Garbarino, J.R., 1996, Methods of analysis by the U.S. Geological Survey National Water Quality Laboratory-In-bottle acid digestion of whole-water samples: U.S. Geological Survey Open-File Report 96-225, 28 p.

Isachsen, Y.W., Landing, E., Lauber, J.M., Rickard, L.V., and Rogers, W.B., eds., 2000, Geology of New York-A simplified account (2d ed.): Albany, N.Y., New York State Museum/Geological Survey, 294 p.

Lee, E.A., and Strahan, A.P., 2003, Methods of analysis by the U.S. Geological Survey Organic Geochemistry Research Group-Determination of acetamide herbicides and their degradations products in water using online solid-phase extraction and liquid chromatography/mass spectrometry: U.S. Geological Survey Open-File Report 03-173, 17 p.

New York State Department of Health, 2007, New York State Health Department public water systems regulations: Albany, N.Y. [variously paged], accessed March 25, 2009, at http://www.health.state.ny.us/environmental/water/drinking/part5/tables.htm

Nystrom, E.A., 2006, Ground-water quality in the Lake Champlain Basin, New York, 2004: U.S. Geological Survey Open-File Report 2006-1088, 22 p., online only at http://pubs.usgs.gov/of/2006/1088/.

Nystrom, E.A., 2007a, Ground-water quality in the St. Lawrence River Basin, New York, 2005-06: U.S. Geological Survey Open-File Report 2007-1066, 33 p., online only at http://pubs.usgs.gov/of/2007/1066/.

Nystrom, E.A., 2007b, Ground-water quality in the Delaware River Basin, New York, 2001 \& 2005-06: U.S. Geological Survey Open-File Report 2007-1098, 36 p., online only at http://pubs.usgs.gov/of/2007/1098/.

Nystrom, E.A., 2008, Ground-water quality in the Mohawk River Basin, New York, 2006: U.S. Geological Survey Open-File Report 2008-1086, 33 p., online only at http://pubs.usgs.gov/of/2008/1086/.

Patton, C.J., and Truitt, E.P., 2000, Methods of analysis by the U.S. Geological Survey National Water Quality Laboratory-Determination of ammonium plus organic nitrogen by a Kjeldahl digestion method and an automated photometric finish that includes digest cleanup by gas diffusion: U.S. Geological Survey Open-File Report 00-170, 31 p.

Phillips, P.J., and Hanchar, D.W., 1996, Water-quality assessment of the Hudson River Basin in New York and adjacent States-Analysis of available nutrient, pesticide, volatile organic compound, and suspended-sediment data, 1970-90: U.S. Geological Survey Water-Resources Investigation Report 96-4065, 77 p. 
Randall, A.D., 1996, Mean annual runoff, precipitation, and evapotranspiration in the glaciated northeastern United States, 1951-80: U.S. Geological Survey Open-File Report 96-395, 2 pl., $1: 250,000$.

Sandstrom, M.W., Stroppel, M.E., Foreman, W.T., and Schroeder, M.P., 2001, Methods of analysis by the U.S. Geological Survey National Water Quality Laboratory-Determination of moderate-use pesticides and selected degradates in water by C-18 solid-phase extraction and gas chromatography/mass spectrometry: U.S. Geological Survey Water-Resources Investigation Report 01-4098, $70 \mathrm{p}$.

Struzeski, T.M., DeGiacomo, W.J., and Zayhowski, E.J., 1996, Methods of analysis by the U.S. Geological Survey National Water Quality Laboratory-Determination of dissolved aluminum and boron in water by inductively coupled plasma-atomic emission spectrometry: U.S. Geological Survey Open-File Report 96-149, 17 p.

U.S. Environmental Protection Agency, 1983, Methods for chemical analysis of water and wastes: Washington, D.C., U.S. Environmental Protection Agency, Environmental Monitoring and Support Laboratory Office of Research and Development, EPA 600/4-79-020, p. 420.2-1-5.

U.S. Environmental Protection Agency, 1997, Guidelines for preparation of the comprehensive state water quality assessments (305(b) Reports) and electronic updates: Washington, D.C., U.S. Environmental Protection Agency, Office of Water, EPA 841-B-97-002A and EPA 841-B-97-002B, PL95-217, $271 \mathrm{p}$.

U.S. Environmental Protection Agency, 1999, Proposed radon in drinking water rule: Washington, D.C., U.S. Environmental Protection Agency, Office of Water, EPA 815-F-99-006, 6 p.

U.S. Environmental Protection Agency, 2003, National primary drinking water standards and national secondary drinking water standards: Washington, D.C., U.S. Environmental Protection Agency, Office of Water, EPA 816-F-03-016, 6 p., available online at http://www.epa.gov/safewater/consumer/pdf/mcl.pdf

U.S. Environmental Protection Agency, 2004, Test methods for evaluating solid wastePhysical/chemical methods: EPA SW-846, p. 9060A1—5, available online at http://www.epa.gov/osw/hazard/testmethods/sw846/pdfs/9060a.pdf

U.S. Geological Survey, variously dated, National field manual for the collection of water-quality data: U.S. Geological Survey Techniques of Water-Resource Investigations, book 9, chaps. A1-A9 [variously paged].

Vogelmann, J.E., Howard, S.M., Yang, L., Larson, C.R., Wylie, B.K., and Van Driel, J.N., 2001, Completion of the 1990's National Land Cover Data Set for the conterminous United States: Photogrammetric Engineering and Remote Sensing, v. 67, p. 650-662. 
Wilde, F.D., Radtke, D.B., Gibs, Jacob, and Iwatsubo, R.T., eds., April 2004, Processing of water samples (version 2.1): U.S. Geological Survey Techniques of Water-Resource Investigations, book 9, chap. A5, accessed January 11, 2007, at http://pubs.water.usgs.gov/twri9A5/.

Zaugg, S.D., Sandstrom, M.W., Smith, S.G., and Fehlberg, K.M., 1995, Methods of analysis by the U.S. Geological Survey National Water Quality Laboratory-Determination of pesticides in water by C-18 solid-phase extraction and capillary-column gas chromatography/mass spectrometry with selected-ion monitoring: U.S. Geological Survey Open-File Report 95-181, 60 p. 


\section{Appendix: Results of Water-Sample Analyses}

The following tables summarize results of the chemical analyses of the 25 samples collected in the Upper Hudson River Basin of eastern New York from August through November 2007.

A1. Constituents that were not detected in groundwater samples collected in the Upper Hudson River Basin, New

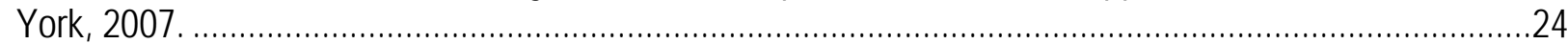

A2 Physical properties of groundwater samples collected in the Upper Hudson River Basin, New York, 2007.....28

A3. Concentrations of major ions in groundwater samples collected in the Upper Hudson River Basin, New York,

2007. 29

A4. Concentrations of nutrients and organic carbon in groundwater samples collected in the Upper Hudson River

Basin, New York, 2007. 31

A5. Concentrations of trace elements and radionuclide activities in groundwater samples collected in the Upper

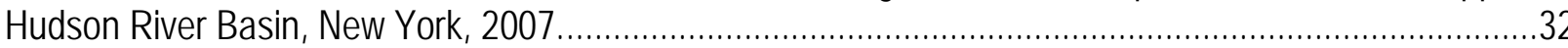

A6. Concentrations of pesticides detected in groundwater samples collected in the Upper Hudson River Basin, New York, 2007.

A7. Concentrations of volatile organic compounds and phenolic compounds detected in groundwater samples collected in the Upper Hudson River Basin, New York, 2007.

A8. Bacteria in groundwater samples collected in the Upper Hudson River Basin, New York, 2007. 
Table A1. Constituents that were not detected in groundwater samples collected in the Upper Hudson River Basin, New York, 2007.

[WY, water year, the 12-month period from October 1 through September 30 of the following year. The water year is designated by the calendar year in which it ends.]

\begin{tabular}{|c|c|c|c|}
\hline \multirow{2}{*}{$\begin{array}{l}\text { U.S. Geological } \\
\text { Survey } \\
\text { parameter code }\end{array}$} & \multirow[b]{2}{*}{ Element or compound } & \multicolumn{2}{|c|}{ Laboratory reporting level } \\
\hline & & WY 2007 & WY 2008 \\
\hline \multicolumn{4}{|c|}{ Trace elements in unfiltered water, micrograms per liter } \\
\hline 71900 & Mercury & 0.010 & 0.010 \\
\hline 01077 & Silver & .02 & .02 \\
\hline \multicolumn{4}{|c|}{ Pesticides in filtered water, micrograms per liter } \\
\hline 50470 & 2,4-D methyl ester & .200 & .200 \\
\hline 39732 & $2,4-\mathrm{D}$ & .04 & .02 \\
\hline 38746 & 2,4-DB & .02 & .02 \\
\hline 82660 & 2,6-Diethylaniline & .002 & .002 \\
\hline 04038 & 2-Chloro-6-ethylamino-4-amino-s-triazine (CEAT) & .08 & .08 \\
\hline 63781 & 2-Chloro- $N$-(2,6-diethylphenyl)acetamide & .02 & .02 \\
\hline 63782 & 2-Chloro- $N$-(2-ethyl-6-methylphenyl)acetamide & .02 & .02 \\
\hline 50355 & $\begin{array}{l}\text { 2-Hydroxy-4-isopropylamino-6-ethylamino-s- } \\
\text { triazine (OIET) }\end{array}$ & .080 & .040 \\
\hline 49308 & 3-Hydroxy carbofuran & .020 & .040 \\
\hline 61029 & Acetochlor ethanesulfonic acid & .02 & .02 \\
\hline 61030 & Acetochlor oxanilic acid & .02 & .02 \\
\hline 62847 & Acetochlor sulfynilacetic acid & .02 & .02 \\
\hline 49260 & Acetochlor & .006 & .006 \\
\hline 49315 & Acifluorfen & .060 & .040 \\
\hline 62849 & Alachlor ethanesulfonic acid secondary amide & .02 & .02 \\
\hline 61031 & Alachlor oxanilic acid & .02 & .02 \\
\hline 62848 & Alachlor sulfynilacetic acid & .02 & .02 \\
\hline 46342 & Alachlor & .005 & .006 \\
\hline 49313 & Aldicarb sulfone & .08 & .08 \\
\hline 49314 & Aldicarb sulfoxide & .040 & .060 \\
\hline 49312 & Aldicarb & .04 & .12 \\
\hline 34253 & alpha-HCH & .002 & .002 \\
\hline 82686 & Azinphos-methyl & .080 & .120 \\
\hline 50299 & Bendiocarb & .04 & .04 \\
\hline 82673 & Benfluralin & .006 & .004 \\
\hline 50300 & Benomyl & .020 & .040 \\
\hline 61693 & Bensulfuron & .06 & .06 \\
\hline 38711 & Bentazon & .02 & .04 \\
\hline 04029 & Bromacil & .04 & .02 \\
\hline 49311 & Bromoxynil & .12 & .12 \\
\hline 04028 & Butylate & .002 & .002 \\
\hline 50305 & Caffeine & .040 & .060 \\
\hline 49310 & Carbaryl & .02 & .04 \\
\hline 82680 & Carbaryl & .060 & .060 \\
\hline 49309 & Carbofuran & .060 & .020 \\
\hline 82674 & Carbofuran & .020 & .020 \\
\hline
\end{tabular}


Table A1. Constituents that were not detected in groundwater samples collected in the Upper Hudson River Basin, New York, 2007.-Continued

[WY, water year, the 12-month period from October 1 through September 30 of the following year. The water year is designated by the calendar year in which it ends.]

\begin{tabular}{|c|c|c|c|}
\hline \multirow{2}{*}{$\begin{array}{l}\text { U.S. Geological } \\
\text { Survey } \\
\text { parameter code }\end{array}$} & \multirow[b]{2}{*}{ Element or compound } & \multicolumn{2}{|c|}{ Laboratory reporting leve } \\
\hline & & WY 2007 & WY 2008 \\
\hline \multicolumn{4}{|c|}{ Pesticides in filtered water, micrograms per liter (continued) } \\
\hline 61188 & Chloramben methyl ester & 0.10 & 0.10 \\
\hline 50306 & Chlorimuron & .080 & .080 \\
\hline 38933 & Chlorpyrifos & .005 & .005 \\
\hline 82687 & cis-Permethrin & .010 & .010 \\
\hline 49305 & Clopyralid & .06 & .06 \\
\hline 04041 & Cyanazine & .018 & .020 \\
\hline 04031 & Cycloate & .06 & .02 \\
\hline 49304 & Dacthal monoacid & .02 & .02 \\
\hline 82682 & DCPA & .003 & .003 \\
\hline 63778 & Dechloroacetochlor & .02 & .02 \\
\hline 63777 & Dechloroalachlor & .02 & .02 \\
\hline 63779 & Dechlorodimethenamid & .02 & .02 \\
\hline 63780 & Dechlorometolachlor & .02 & .02 \\
\hline 62170 & Desulfinyl fipronil & .012 & .012 \\
\hline 39572 & Diazinon & .005 & .005 \\
\hline 49302 & Dichlorprop & .04 & .02 \\
\hline 39381 & Dieldrin & .009 & .009 \\
\hline 61951 & Dimethenamid ethanesulfonic acid & .02 & .02 \\
\hline 62482 & Dimethenamid oxanilic acid & .02 & .02 \\
\hline 61588 & Dimethenamid & .02 & .02 \\
\hline 49301 & Dinoseb & .04 & .04 \\
\hline 04033 & Diphenamid & .04 & .04 \\
\hline 82677 & Disulfoton & .02 & .04 \\
\hline 49300 & Diuron & .04 & .04 \\
\hline 82668 & EPTC & .002 & .002 \\
\hline 82663 & Ethalfluralin & .009 & .009 \\
\hline 82672 & Ethoprop & .012 & .012 \\
\hline 49297 & Fenuron & .04 & .04 \\
\hline 62169 & Desulfinylfipronil amide & .029 & .029 \\
\hline 62167 & Fipronil sulfide & .013 & .013 \\
\hline 62168 & Fipronil sulfone & .024 & .024 \\
\hline 61952 & Flufenacet ethanesulfonic acid & .02 & .02 \\
\hline 62483 & Flufenacet oxanilic acid & .02 & .02 \\
\hline 62481 & Flufenacet & .02 & .02 \\
\hline 61694 & Flumetsulam & .06 & .06 \\
\hline 38811 & Fluometuron & .04 & .04 \\
\hline 04095 & Fonofos & .006 & .010 \\
\hline 63784 & Hydroxyacetochlor & .02 & .02 \\
\hline 63783 & Hydroxyalachlor & .02 & .02 \\
\hline 64045 & Hydroxydimethenamid & .02 & .02 \\
\hline
\end{tabular}


Table A1. Constituents that were not detected in groundwater samples collected in the Upper Hudson River Basin, New York, 2007.-Continued

[WY, water year, the 12-month period from October 1 through September 30 of the following year. The water year is designated by the calendar year in which it ends.]

\begin{tabular}{|c|c|c|c|}
\hline \multirow{2}{*}{$\begin{array}{l}\text { U.S. Geological } \\
\text { Survey } \\
\text { parameter code }\end{array}$} & \multirow[b]{2}{*}{ Element or compound } & \multicolumn{2}{|c|}{ Laboratory reporting level } \\
\hline & & WY 2007 & WY 2008 \\
\hline \multicolumn{4}{|c|}{ Pesticides in filtered water, micrograms per liter (continued) } \\
\hline 63785 & Hydroxymetolachlor & 0.02 & 0.02 \\
\hline 50356 & Imazaquin & .04 & .04 \\
\hline 50407 & Imazethapyr & .04 & .04 \\
\hline 61695 & Imidacloprid & .060 & .060 \\
\hline 39341 & Lindane & .004 & .006 \\
\hline 38478 & Linuron & .04 & .02 \\
\hline 82666 & Linuron & .060 & .060 \\
\hline 39532 & Malathion & .016 & .016 \\
\hline 38482 & MCPA & .06 & .06 \\
\hline 38487 & МСРВ & .20 & .06 \\
\hline 38501 & Methiocarb & .040 & .040 \\
\hline 49296 & Methomyl & .060 & .120 \\
\hline 82667 & Methyl parathion & .008 & .008 \\
\hline 39415 & Metolachlor & .010 & .010 \\
\hline 82630 & Metribuzin & .012 & .012 \\
\hline 61697 & Metsulfuron & .14 & .14 \\
\hline 82671 & Molinate & .002 & .002 \\
\hline 61692 & $N$-(4-Chlorophenyl)- $N$ '-methylurea & .06 & .12 \\
\hline 82684 & Napropamide & .018 & .018 \\
\hline 49294 & Neburon & .02 & .02 \\
\hline 50364 & Nicosulfuron & .10 & .10 \\
\hline 49293 & Norflurazon & .04 & .02 \\
\hline 49292 & Oryzalin & .04 & .04 \\
\hline 38866 & Oxamyl & .04 & .12 \\
\hline 34653 & $p, p^{\prime}-\mathrm{DDE}$ & .003 & .003 \\
\hline 39542 & Parathion & .010 & .010 \\
\hline 82669 & Pebulate & .004 & .005 \\
\hline 82683 & Pendimethalin & .020 & .012 \\
\hline 82664 & Phorate & .020 & .040 \\
\hline 49291 & Picloram & .12 & .12 \\
\hline 04037 & Prometon & .01 & .01 \\
\hline 82676 & Propyzamide & .004 & .004 \\
\hline 62766 & Propachlor ethanesulfonic acid & .05 & .05 \\
\hline 62767 & Propachlor oxanilic acid & .02 & .02 \\
\hline 04024 & Propachlor & .010 & .006 \\
\hline 82679 & Propanil & .011 & .006 \\
\hline 82685 & Propargite & .02 & .04 \\
\hline 49236 & Propham & .060 & .040 \\
\hline 50471 & Propiconazole & .06 & .04 \\
\hline 38538 & Propoxur & .040 & .040 \\
\hline
\end{tabular}


Table A1. Constituents that were not detected in groundwater samples collected in the Upper Hudson River Basin, New York, 2007.-Continued

[WY, water year, the 12-month period from October 1 through September 30 of the following year. The water year is designated by the calendar year in which it ends.]

\begin{tabular}{|c|c|c|c|}
\hline \multirow{2}{*}{$\begin{array}{l}\text { U.S. Geological } \\
\text { Survey parameter } \\
\text { code }\end{array}$} & \multirow[b]{2}{*}{ Element or compound } & \multicolumn{2}{|c|}{ Laboratory reporting leve } \\
\hline & & WY 2007 & WY 2008 \\
\hline \multicolumn{4}{|c|}{ Pesticides in filtered water, micrograms per liter (continued) } \\
\hline 38548 & Siduron & 0.04 & 0.02 \\
\hline 50337 & Sulfometuron & .060 & .060 \\
\hline 82670 & Tebuthiuron & .02 & .02 \\
\hline 82665 & Terbacil & .040 & .018 \\
\hline 04032 & Terbacil & .040 & .040 \\
\hline 82675 & Terbufos & .01 & .02 \\
\hline 82681 & Thiobencarb & .010 & .010 \\
\hline 82678 & Triallate & .006 & .006 \\
\hline 49235 & Triclopyr & .04 & .08 \\
\hline 82661 & Trifluralin & .006 & .006 \\
\hline \multicolumn{4}{|c|}{ Volatile organic compounds in unfiltered water, micrograms per liter } \\
\hline 34506 & 1,1,1-Trichloroethane & .1 & .1 \\
\hline 77652 & 1,1,2-Trichloro-1,2,2-trifluoroethane & .1 & .1 \\
\hline 34496 & 1,1-Dichloroethane & .1 & .1 \\
\hline 34501 & 1,1-Dichloroethene & .1 & .1 \\
\hline 34536 & 1,2-Dichlorobenzene & .1 & .1 \\
\hline 32103 & 1,2-Dichloroethane & .2 & .2 \\
\hline 34541 & 1,2-Dichloropropane & .1 & .1 \\
\hline 34566 & 1,3-Dichlorobenzene & .1 & .1 \\
\hline 34571 & 1,4-Dichlorobenzene & .1 & .1 \\
\hline 34030 & Benzene & .1 & .1 \\
\hline 34301 & Chlorobenzene & .1 & .1 \\
\hline 77093 & cis-1,2-Dichloroethene & .1 & .1 \\
\hline 34668 & Dichlorodifluoromethane & .2 & .2 \\
\hline 34423 & Dichloromethane & .2 & .2 \\
\hline 81576 & Diethyl ether & .2 & .2 \\
\hline 81577 & Diisopropyl ether & .2 & .2 \\
\hline 34371 & Ethylbenzene & .1 & .1 \\
\hline 50005 & Methyl tert-pentyl ether & .2 & .2 \\
\hline 85795 & $m$-Xylene plus $p$-xylene & .2 & .2 \\
\hline 77135 & $o$-Xylene & .1 & .1 \\
\hline 77128 & Styrene & .1 & .1 \\
\hline 50004 & tert-Butyl ethyl ether & .1 & .1 \\
\hline 32102 & Tetrachloromethane & .2 & .2 \\
\hline 34546 & trans-1,2-Dichloroethene & .1 & .1 \\
\hline 32104 & Tribromomethane & .2 & .2 \\
\hline 39180 & Trichloroethene & .1 & .1 \\
\hline 34488 & Trichlorofluoromethane & .2 & .2 \\
\hline 39175 & Vinyl chloride & .2 & .2 \\
\hline
\end{tabular}


Table A2. Physical properties of groundwater samples collected in the Upper Hudson River Basin, New York, 2007.

[mg/L, milligrams per liter; $\mu \mathrm{S} / \mathrm{cm}$, microsiemens per centimeter at 25 degrees Celsius; (00080), U.S. Geological Survey National Water Information System parameter code; <, less than. Bold values exceed one or more drinking-water standards. Well locations are shown in fig. 2.]

\begin{tabular}{|c|c|c|c|c|c|}
\hline $\begin{array}{c}\text { Well } \\
\text { number }{ }^{1}\end{array}$ & $\begin{array}{c}\text { Color, } \\
\text { platinum-cobalt } \\
\text { units } \\
(00080) \\
\end{array}$ & $\begin{array}{c}\text { Dissolved oxygen, } \\
\mathrm{mg} / \mathrm{L} \\
(00300)\end{array}$ & $\begin{array}{c}\mathrm{pH}, \\
\text { field, } \\
\text { standard units } \\
(00400)\end{array}$ & $\begin{array}{c}\text { Specific } \\
\text { conductance, } \\
\text { field } \\
\mu S / \mathrm{cm} \\
(00095) \\
\end{array}$ & $\begin{array}{c}\text { Water } \\
\text { temperature, } \\
\text { degrees Celsius } \\
(00010)\end{array}$ \\
\hline \multicolumn{6}{|c|}{ Sand and gravel wells } \\
\hline EX159 & 5 & 5.1 & 7.0 & 222 & 8.9 \\
\hline FU273 & $<1$ & 6.5 & 6.9 & 926 & 10.5 \\
\hline H296 & 5 & 8.9 & 7.5 & 186 & 7.6 \\
\hline RE889 & 5 & 3.9 & 6.8 & 643 & 10.9 \\
\hline RE1768 & 8 & .2 & 7.3 & 633 & 9.9 \\
\hline SA879 & 2 & 6.5 & 6.5 & 58 & 10.4 \\
\hline SA2742 & 5 & 8.5 & 7.9 & 550 & 10.9 \\
\hline SA3644 & 5 & 8.9 & 7.8 & 730 & 9.5 \\
\hline SA4024 & 2 & 2.5 & 6.8 & 1,100 & 10.9 \\
\hline SA4987 & 2 & .5 & 7.9 & 370 & 8.7 \\
\hline W1419 & 5 & $<.1$ & 7.6 & 339 & 9.2 \\
\hline WR83 & 2 & 5.9 & ${ }^{2} 7.0$ & 319 & 9.8 \\
\hline WR85 & 5 & 5.4 & 6.8 & 806 & 9.7 \\
\hline \multicolumn{6}{|c|}{ Bedrock wells } \\
\hline EX797 & 2 & .1 & 7.3 & 362 & 8.6 \\
\hline EX1143 & 5 & 7.5 & 7.6 & 333 & 8.3 \\
\hline H56 & 5 & 10.3 & 7.9 & 241 & 8.1 \\
\hline H401 & 8 & .6 & 7.6 & 201 & 9.0 \\
\hline H453 & 2 & 4.2 & 6.8 & 150 & 11.5 \\
\hline RE2694 & 35 & .2 & 9.3 & 395 & 13.5 \\
\hline SA4346 & 5 & .2 & 8.8 & 374 & 11.0 \\
\hline W1274 & 5 & 6.1 & 6.9 & 584 & 10.4 \\
\hline W1284 & 2 & .3 & 7.8 & 402 & 10.5 \\
\hline WR1106 & 2 & 5.0 & 8.3 & 129 & 9.1 \\
\hline WR1280 & 15 & .2 & 8.0 & 222 & 8.9 \\
\hline WR1849 & 5 & .3 & 8.4 & 103 & 9.5 \\
\hline
\end{tabular}

${ }^{1}$ EX, Essex County; FU, Fulton County; H, Hamilton County; RE, Rensselaer County; SA, Saratoga County; W, Washington County; WR, Warren County.

${ }^{2}$ Laboratory value. 
Table A3. Concentrations of major ions in groundwater samples collected in the Upper Hudson River Basin, New York, 2007.

[mg/L, milligrams per liter; $\mathrm{CaCO}_{3}$; calcium carbonate; (00900), U.S. Geological Survey National Water Information System parameter code; <, less than; E, estimated value. Bold values exceed one or more drinking-water standards. Well locations are shown in fig. 2.]

\begin{tabular}{|c|c|c|c|c|c|c|c|}
\hline $\begin{array}{c}\text { Well } \\
\text { number }{ }^{1}\end{array}$ & $\begin{array}{c}\text { Hardness, } \\
\mathrm{mg} / \mathrm{L} \text { as } \\
\mathrm{CaCO}_{3} \\
(00900)\end{array}$ & $\begin{array}{c}\text { Calcium, } \\
\text { filtered, } \\
\text { mg/L } \\
(00915)\end{array}$ & $\begin{array}{l}\text { Magnesium, } \\
\text { filtered, } \\
\mathrm{mg} / \mathrm{L} \\
(00925)\end{array}$ & $\begin{array}{l}\text { Potassium, } \\
\text { filtered, } \\
\text { mg/L } \\
(00935) \\
\end{array}$ & $\begin{array}{c}\text { Sodium, } \\
\text { filtered, } \\
\mathrm{mg} / \mathrm{L} \\
(00930)\end{array}$ & $\begin{array}{l}\text { Acid neutralizing } \\
\text { capacity, } \\
\text { unfiltered, } \\
\text { mg/L as } \mathrm{CaCO}_{3} \\
(90410)\end{array}$ & $\begin{array}{c}\text { Alkalinity, } \\
\text { filtered, } \\
\text { fixed end point, lab } \\
\text { mg/L as } \mathrm{CaCO}_{3} \\
(29801)\end{array}$ \\
\hline \multicolumn{8}{|c|}{ Sand and gravel wells } \\
\hline EX159 & 110 & 32.1 & 6.19 & 0.68 & 8.84 & 57 & 57 \\
\hline FU273 & 360 & 105 & 22.7 & 2.02 & 50.1 & 187 & 213 \\
\hline H296 & 83 & 30.5 & 1.65 & .44 & 3.15 & 83 & 83 \\
\hline RE889 & 160 & 49.7 & 8.07 & 2.42 & 63.6 & 123 & 122 \\
\hline RE1768 & 220 & 68.0 & 12.8 & 1.85 & 38.4 & 216 & 216 \\
\hline SA879 & 22 & 6.27 & 1.60 & .50 & 1.77 & 21 & 21 \\
\hline SA2742 & 120 & 36.1 & 8.43 & 1.05 & 53.5 & 72 & 73 \\
\hline SA3644 & 290 & 74.5 & 25.8 & 1.93 & 12.4 & 49 & 49 \\
\hline SA4024 & 290 & 83.2 & 19.0 & 3.27 & 105 & 203 & 196 \\
\hline SA4987 & 120 & 38.5 & 6.93 & .70 & 19.4 & 101 & 101 \\
\hline W1419 & 160 & 53.1 & 6.09 & 1.50 & 5.40 & 143 & 142 \\
\hline WR83 & 110 & 30.8 & 6.95 & 1.01 & 34.3 & 67 & 67 \\
\hline WR85 & 140 & 44.0 & 7.02 & 1.47 & 93.7 & 97 & 97 \\
\hline \multicolumn{8}{|c|}{ Bedrock wells } \\
\hline EX797 & 180 & 53.7 & 10.4 & .96 & 2.63 & 101 & 101 \\
\hline EX1143 & 170 & 61.1 & 4.63 & .82 & 1.82 & 153 & 152 \\
\hline H56 & 100 & 29.7 & 7.28 & .85 & 5.15 & 83 & 83 \\
\hline $\mathrm{H} 401$ & 88 & 26.4 & 5.46 & .68 & 3.45 & 74 & 73 \\
\hline $\mathrm{H} 453$ & 63 & 20.1 & 3.10 & .49 & 3.92 & 50 & 50 \\
\hline RE2694 & 36 & 8.32 & 3.75 & 1.67 & 80.1 & 207 & 214 \\
\hline SA4346 & 11 & 2.52 & 1.22 & .98 & 87.7 & 202 & 202 \\
\hline W1274 & 240 & 75.0 & 12.2 & 14.7 & 17.3 & 164 & 164 \\
\hline W1284 & 110 & 30.5 & 9.19 & 2.24 & 37.6 & 162 & 162 \\
\hline WR1106 & 62 & 19.9 & 3.09 & .80 & 1.31 & 59 & 59 \\
\hline WR1280 & 97 & 33.9 & 3.01 & .52 & 8.49 & 111 & 111 \\
\hline WR1849 & 40 & 12.5 & 2.17 & .74 & 6.12 & 51 & 50 \\
\hline
\end{tabular}

${ }^{1}$ EX, Essex County; FU, Fulton County; H, Hamilton County; RE, Rensselaer County; SA, Saratoga County; W, Washington County; WR, Warren County. 
Table A3. Concentrations of major ions in groundwater samples collected in the Upper Hudson River Basin, New York, 2007. - Continued

[mg/L, milligrams per liter; $\mathrm{CaCO}_{3}$; calcium carbonate; (00900), U.S. Geological Survey National Water Information System parameter code; <, less than; E, estimated value. Bold values exceed one or more drinking-water standards. Well locations are shown in fig. 2.]

\begin{tabular}{|c|c|c|c|c|c|c|}
\hline $\begin{array}{c}\text { Well } \\
\text { number }{ }^{1}\end{array}$ & $\begin{array}{c}\text { Bicarbonate }{ }^{2}, \\
\text { filtered, } \\
\text { fixed end point, } \\
\text { lab, mg/L } \\
(29805) \\
\end{array}$ & $\begin{array}{c}\text { Chloride, } \\
\text { filtered, } \\
\mathrm{mg} / \mathrm{L} \\
(00940)\end{array}$ & $\begin{array}{c}\text { Fluoride, } \\
\text { filtered, } \\
\mathrm{mg} / \mathrm{L} \\
(00950)\end{array}$ & $\begin{array}{c}\text { Silica, } \\
\text { filtered, } \\
\text { mg/L } \\
(00955)\end{array}$ & $\begin{array}{c}\text { Sulfate, } \\
\text { filtered, } \\
\mathrm{mg} / \mathrm{L} \\
(00945)\end{array}$ & $\begin{array}{c}\text { Residue on } \\
\text { evaporation, } \\
\text { filtered, } \\
\mathrm{mg} / \mathrm{L} \\
(70300)\end{array}$ \\
\hline \multicolumn{7}{|c|}{ Sand and gravel wells } \\
\hline EX159 & 70 & 42.4 & $<0.10$ & 13.3 & 10.8 & 190 \\
\hline FU273 & 260 & 104 & $<.10$ & 11.5 & 21.5 & 482 \\
\hline H296 & 101 & 4.50 & $<.12$ & 7.00 & 5.04 & 110 \\
\hline RE889 & 149 & 107 & Е .07 & 7.63 & 13.0 & 347 \\
\hline RE1768 & 264 & 61.4 & Е .07 & 7.82 & 19.7 & 353 \\
\hline SA879 & 26 & 1.05 & E.05 & 14.9 & 5.75 & 39 \\
\hline SA2742 & 89 & 79.1 & $<.12$ & 16.9 & 18.5 & 317 \\
\hline SA3644 & 60 & 178 & $<.10$ & 18.4 & 10.3 & 504 \\
\hline SA4024 & 239 & 215 & E.05 & 13.4 & 21.6 & 609 \\
\hline SA4987 & 123 & 36.8 & E.06 & 8.54 & 21.1 & 199 \\
\hline W1419 & 173 & 7.96 & $<.12$ & 7.11 & 23.9 & 200 \\
\hline WR83 & 82 & 73.2 & Е .07 & 9.13 & 9.54 & 217 \\
\hline WR85 & 118 & 175 & $<.12$ & 13.3 & 9.74 & 424 \\
\hline \multicolumn{7}{|c|}{ Bedrock wells } \\
\hline EX797 & 123 & .60 & .14 & 14.4 & 82.3 & 240 \\
\hline EX1143 & 185 & 4.61 & .17 & 13.0 & 18.2 & 204 \\
\hline H56 & 101 & 16.6 & .47 & 15.3 & 10.4 & 157 \\
\hline H401 & 89 & 13.4 & .12 & 23.3 & 5.69 & 134 \\
\hline H453 & 61 & 6.39 & .34 & 12.7 & 9.86 & 102 \\
\hline RE2694 & 261 & .43 & .43 & 9.66 & 1.83 & 228 \\
\hline SA4346 & 246 & 2.44 & 1.31 & 7.00 & $<.18$ & 223 \\
\hline W1274 & 200 & 29.7 & Е .06 & 10.5 & 36.8 & 338 \\
\hline W1284 & 198 & 14.1 & .45 & 9.05 & 28.0 & 230 \\
\hline WR1106 & 72 & .53 & .25 & 17.2 & 6.99 & 82 \\
\hline WR1280 & 135 & .64 & 1.36 & 19.3 & 3.31 & 148 \\
\hline WR1849 & 61 & .39 & .31 & 14.1 & 3.11 & 80 \\
\hline
\end{tabular}

${ }^{1}$ EX, Essex County; FU, Fulton County; H, Hamilton County; RE, Rensselaer County; SA, Saratoga County; W, Washington County; WR, Warren County.

${ }^{2}$ Bicarbonate concentration calculated from alkalinity. 
Table A4. Concentrations of nutrients and organic carbon in groundwater samples collected in the Upper Hudson River Basin, New York, 2007.

[N, nitrogen; P, phosphorus; mg/L, milligrams per liter; (00623), U.S. Geological Survey National Water Information System parameter code; <, less than; E, estimated value. Bold values exceed one or more drinking-water standard. Well locations are shown in fig. 2.]

\begin{tabular}{|c|c|c|c|c|c|c|}
\hline $\begin{array}{c}\text { Well } \\
\text { number }{ }^{1}\end{array}$ & $\begin{array}{l}\text { Ammonia plus } \\
\text { organic-N, } \\
\text { filtered, } \\
\text { mg/L as N } \\
(00623)\end{array}$ & $\begin{array}{l}\text { Ammonia, } \\
\text { filtered, } \\
\text { mg/L as N } \\
(00608)\end{array}$ & $\begin{array}{l}\text { Nitrate plus } \\
\text { nitrite, } \\
\text { filtered, } \\
\text { mg/L as N } \\
\text { (00631) }\end{array}$ & $\begin{array}{l}\text { Nitrite, } \\
\text { filtered, } \\
\text { mg/L as N } \\
\text { (00613) }\end{array}$ & $\begin{array}{l}\text { Ortho- } \\
\text { phosphate, } \\
\text { filtered, } \\
\text { mg/L as P } \\
\text { (00671) }\end{array}$ & $\begin{array}{c}\text { Organic } \\
\text { carbon, } \\
\text { unfiltered, } \\
\text { mg/L } \\
(00680)\end{array}$ \\
\hline \multicolumn{7}{|c|}{ Sand and gravel wells } \\
\hline EX159 & E 0.05 & $<0.020$ & 0.21 & $<0.002$ & 0.010 & $<1.0$ \\
\hline FU273 & E.06 & $<.020$ & 2.25 & $<.002$ & .008 & 1.9 \\
\hline H296 & $<.14$ & $<.020$ & .40 & $<.002$ & E. .006 & $<1.0$ \\
\hline RE889 & $<.14$ & $<.020$ & 2.65 & $<.002$ & .006 & $<1.0$ \\
\hline RE1768 & Е.07 & .043 & .06 & .003 & .010 & 1.1 \\
\hline SA879 & $<.10$ & $<.020$ & .09 & $<.002$ & .008 & $<1.0$ \\
\hline SA2742 & $<.14$ & E. .012 & 11.1 & $<.002$ & .006 & $<1.0$ \\
\hline SA3644 & $<.10$ & $<.020$ & .47 & $<.002$ & .018 & $<1.0$ \\
\hline SA4024 & .21 & .138 & .58 & .003 & .007 & 1.9 \\
\hline SA4987 & $<.14$ & Е .014 & .22 & .064 & .006 & 1.0 \\
\hline W1419 & $<.14$ & E. .011 & Е .03 & .010 & E. .003 & $<1.0$ \\
\hline WR83 & $<.10$ & $<.020$ & 1.34 & $<.002$ & .012 & 1.3 \\
\hline WR85 & Е.07 & $<.020$ & .95 & $<.002$ & .016 & $<1.0$ \\
\hline \multicolumn{7}{|c|}{ Bedrock wells } \\
\hline EX797 & $<.10$ & E.020 & $<.06$ & $<.002$ & .015 & 1.3 \\
\hline EX1143 & $<.14$ & $<.020$ & 1.25 & $<.002$ & E.004 & 1.1 \\
\hline H56 & $<.10$ & E. .014 & .80 & .002 & .016 & $<1.0$ \\
\hline H401 & E.10 & .095 & $<.06$ & .002 & .146 & 1.3 \\
\hline H453 & $<.10$ & $<.020$ & .68 & $<.002$ & E. 005 & $<1.0$ \\
\hline RE2694 & .55 & .505 & $<.06$ & $<.002$ & .024 & $<1.0$ \\
\hline SA4346 & .39 & .355 & $<.04$ & $<.002$ & .046 & $<1.0$ \\
\hline W1274 & E.10 & $<.020$ & 13.1 & $<.002$ & Е .004 & 1.8 \\
\hline W1284 & $<.14$ & .067 & $<.04$ & $<.002$ & .007 & $<1.0$ \\
\hline WR1106 & $<.14$ & $<.020$ & .08 & $<.002$ & .007 & $<1.0$ \\
\hline WR1280 & $<.10$ & $<.020$ & $<.06$ & E. .001 & .007 & 2.8 \\
\hline WR1849 & $<.10$ & $<.020$ & E.05 & .005 & .045 & $<1.0$ \\
\hline
\end{tabular}

${ }^{1}$ EX, Essex County; FU, Fulton County; H, Hamilton County; RE, Rensselaer County; SA, Saratoga County; W, Washington County; WR, Warren County. 
Table A5. Concentrations of trace elements and radionuclide activities in groundwater samples collected in the Upper Hudson River Basin, New York, 2007.

[ $\mu \mathrm{g} / \mathrm{L}$, micrograms per liter; (01105), U.S. Geological Survey National Water Information System parameter code; <, less than; E, estimated value; M, presence verified but not quantified. Bold values exceed one or more drinking-water standards. Well locations are shown in fig. 2.]

\begin{tabular}{|c|c|c|c|c|c|c|c|c|}
\hline $\begin{array}{c}\text { Well } \\
\text { number }{ }^{1}\end{array}$ & $\begin{array}{c}\text { Aluminum, } \\
\text { unfiltered, } \\
\mu \mathrm{g} / \mathrm{L} \\
(01105) \\
\end{array}$ & $\begin{array}{c}\text { Antimony, } \\
\text { unfiltered, } \\
\mu \mathrm{g} / \mathrm{L} \\
(01097)\end{array}$ & $\begin{array}{c}\text { Arsenic, } \\
\text { unfiltered, } \\
\mu \mathrm{g} / \mathrm{L} \\
(01002)\end{array}$ & $\begin{array}{c}\text { Barium, } \\
\text { unfiltered, } \\
\mu \mathrm{g} / \mathrm{L} \\
(01007)\end{array}$ & $\begin{array}{c}\text { Beryllium, } \\
\text { unfiltered, } \\
\mu \mathrm{g} / \mathrm{L} \\
(01012)\end{array}$ & $\begin{array}{c}\text { Boron, } \\
\text { filtered, } \\
\mu \mathrm{g} / \mathrm{L} \\
(01020)\end{array}$ & $\begin{array}{c}\text { Cadmium, } \\
\text { unfiltered, } \\
\mu \mathrm{g} / \mathrm{L} \\
(01027) \\
\end{array}$ & $\begin{array}{c}\text { Chromium, } \\
\text { unfiltered, } \\
\mu \mathrm{g} / \mathrm{L} \\
(01034) \\
\end{array}$ \\
\hline \multicolumn{9}{|c|}{ Sand and gravel wells } \\
\hline EX159 & E 2 & $<0.2$ & 0.44 & 2.8 & $<0.06$ & 7.5 & $<0.02$ & $<0.60$ \\
\hline FU273 & $<2$ & $<.2$ & E .14 & 38.6 & $<.06$ & 24 & $<.02$ & E. .55 \\
\hline H296 & E 3 & $<.1$ & $<.60$ & 7.3 & $<.04$ & 5.2 & $<.01$ & E.34 \\
\hline RE889 & $<4$ & $<.1$ & $<.60$ & 25.2 & $<.04$ & 28 & $<.01$ & E. .27 \\
\hline RE1768 & $<4$ & E.1 & 1.3 & 216 & $<.04$ & 14 & .02 & $<.40$ \\
\hline SA879 & E 1 & $<.2$ & $<.20$ & 1.4 & $<.06$ & 4.0 & $<.02$ & E.31 \\
\hline SA2742 & E 2 & $<.1$ & $<.60$ & 11.1 & $<.04$ & 110 & .02 & .54 \\
\hline SA3644 & 2 & $<.2$ & $<.20$ & 5.1 & $<.06$ & 4.6 & $<.02$ & 1.1 \\
\hline SA4024 & $<2$ & $<.2$ & $<.20$ & 37.6 & $<.06$ & 22 & .16 & $<.60$ \\
\hline SA4987 & $<4$ & $<.1$ & 1.6 & 27.7 & $<.04$ & 14 & .02 & $<.40$ \\
\hline W1419 & $<4$ & $<.1$ & .75 & 148 & $<.04$ & 9.0 & E.01 & $<.40$ \\
\hline WR83 & 2 & $<.2$ & $<.20$ & 10.3 & $<.06$ & 7.3 & .02 & $<.60$ \\
\hline WR85 & E 2 & $<.1$ & $<.60$ & 5.7 & $<.04$ & 12 & $<.01$ & $<.40$ \\
\hline \multicolumn{9}{|c|}{ Bedrock wells } \\
\hline EX797 & 4 & $<.2$ & E.20 & 16.0 & $<.06$ & 66 & .02 & $<.60$ \\
\hline EX1143 & $<4$ & E.1 & E.49 & 3.7 & $<.04$ & 49 & .03 & $<.40$ \\
\hline H56 & 44 & $<.2$ & $<.20$ & 3.2 & $<.06$ & 11 & $<.02$ & 1.1 \\
\hline $\mathrm{H} 401$ & 5 & $<.2$ & .57 & 6.6 & $<.06$ & 6.8 & $<.02$ & $<.60$ \\
\hline H453 & 120 & $<.2$ & $<.20$ & 1.4 & $<.06$ & 4.5 & E .01 & $<.60$ \\
\hline RE2694 & 2,100 & E.2 & .85 & 507 & .09 & 266 & E.01 & 2.7 \\
\hline SA4346 & 63 & $<.1$ & $<.60$ & 113 & $<.04$ & 248 & .06 & .60 \\
\hline W1274 & 6 & .3 & E. 56 & 146 & $<.04$ & 33 & .11 & $<.40$ \\
\hline W1284 & $<4$ & E.1 & 3.7 & 135 & $<.04$ & 148 & .02 & $<.40$ \\
\hline WR1106 & $<4$ & $<.1$ & E.37 & 1.7 & $<.04$ & 8.6 & $<.01$ & .62 \\
\hline WR1280 & 4 & $<.2$ & 2.4 & 5.2 & $<.06$ & 64 & $<.02$ & $<.60$ \\
\hline WR1849 & 3 & $<.2$ & E.13 & 1.1 & $<.06$ & 11 & $<.02$ & E .52 \\
\hline
\end{tabular}

${ }^{1}$ EX, Essex County; FU, Fulton County; H, Hamilton County; RE, Rensselaer County; SA, Saratoga County; W, Washington County; WR, Warren County. 
Table A5. Concentrations of trace elements and radionuclide activities in groundwater samples collected in the Upper Hudson River Basin, New York, 2007. —Continued

[ $\mu \mathrm{g} / \mathrm{L}$, micrograms per liter; (01037), U.S. Geological Survey National Water Information System parameter code; <, less than; E, estimated value; M, presence verified but not quantified. Bold values exceed one or more drinking-water standard. Well locations are shown in fig. 2.]

\begin{tabular}{|c|c|c|c|c|c|c|c|c|}
\hline $\begin{array}{c}\text { Well } \\
\text { number }{ }^{1}\end{array}$ & $\begin{array}{c}\text { Cobalt, } \\
\text { unfiltered, } \\
\mu \mathrm{g} / \mathrm{L} \\
(01037)\end{array}$ & $\begin{array}{c}\text { Copper, } \\
\text { unfiltered, } \\
\mu \mathrm{g} / \mathrm{L} \\
(01042)\end{array}$ & $\begin{array}{c}\text { Iron, } \\
\text { filtered, } \\
\mu \mathrm{g} / \mathrm{L} \\
(01046)\end{array}$ & $\begin{array}{c}\text { Iron, } \\
\text { unfiltered, } \\
\mu \mathrm{g} / \mathrm{L} \\
(01045)\end{array}$ & $\begin{array}{c}\text { Lead, } \\
\text { unfiltered, } \\
\mu \mathrm{g} / \mathrm{L} \\
(01051)\end{array}$ & $\begin{array}{c}\text { Lithium, } \\
\text { unfiltered, } \\
\mu \mathrm{g} / \mathrm{L} \\
(01132)\end{array}$ & $\begin{array}{c}\text { Manganese, } \\
\text { filtered, } \\
\mu \mathrm{g} / \mathrm{L} \\
(01056)\end{array}$ & $\begin{array}{c}\text { Manganese, } \\
\text { unfiltered, } \\
\mu \mathrm{g} / \mathrm{L} \\
(01055) \\
\end{array}$ \\
\hline \multicolumn{9}{|c|}{ Sand and gravel wells } \\
\hline EX159 & $<0.04$ & $<1.2$ & $<6$ & $<6$ & 0.23 & 1.0 & 1.1 & 1.0 \\
\hline FU273 & .05 & 3.0 & $<6$ & $<6$ & .19 & 1.1 & .7 & .7 \\
\hline H296 & $<.04$ & 12.4 & $<8$ & $<6$ & E.05 & $<.4$ & $<.4$ & $<.4$ \\
\hline RE889 & .12 & $<1.2$ & $<8$ & $<6$ & .22 & 2.0 & $<.4$ & $<.8$ \\
\hline RE1768 & .09 & $<1.2$ & 149 & 150 & .12 & 2.9 & 285 & 306 \\
\hline SA879 & $<.04$ & 12.5 & $<6$ & E 4 & .16 & E. .5 & .4 & $<.6$ \\
\hline SA2742 & .13 & 2.8 & 16 & 190 & .09 & 1.3 & 2.8 & 4.0 \\
\hline SA3644 & $<.04$ & 3.9 & 12 & 80 & Е .06 & .7 & 4.7 & 5.1 \\
\hline SA4024 & .61 & 2.1 & 43 & 42 & .40 & 6.1 & 776 & 780 \\
\hline SA4987 & $<.04$ & $<1.2$ & 28 & 35 & 1.41 & 3.1 & 22.2 & 22.4 \\
\hline W1419 & .11 & $<1.2$ & 98 & 142 & E.04 & 3.7 & 90.2 & 96.8 \\
\hline WR83 & Е.03 & 50.3 & 31 & 39 & 3.77 & $<.6$ & .5 & E. 3 \\
\hline WR85 & E.02 & 6.5 & E 5 & E 5 & $<.06$ & .5 & E.4 & $<.8$ \\
\hline \multicolumn{9}{|c|}{ Bedrock wells } \\
\hline EX797 & .10 & $<1.2$ & 16 & 51 & .17 & 3.2 & 82.2 & 88.1 \\
\hline EX1143 & Е.02 & 9.8 & $<8$ & $<6$ & .32 & 4.5 & E .4 & .5 \\
\hline H56 & .04 & 4.9 & $<6$ & $<6$ & 1.32 & 3.1 & E.1 & $<.6$ \\
\hline H401 & Е .02 & $<1.2$ & 43 & 201 & .24 & 1.2 & 342 & 334 \\
\hline H453 & .04 & 12.0 & $<6$ & 110 & .36 & 1.0 & .5 & 2.1 \\
\hline RE2694 & .59 & E 1.1 & 14 & 2,110 & .71 & 148 & 17.7 & 52.3 \\
\hline SA4346 & Е.03 & $<1.2$ & 14 & 106 & .14 & 58.8 & 2.4 & 3.4 \\
\hline W1274 & .06 & 13.1 & E 6 & 11 & .56 & 16.3 & .6 & 1.0 \\
\hline W1284 & .25 & $<1.2$ & $<8$ & 32 & 1.34 & 62.7 & 111 & 115 \\
\hline WR1106 & $<.04$ & 5.6 & $<8$ & $<6$ & .12 & 1.1 & $<.4$ & $<.4$ \\
\hline WR1280 & Е.02 & $<1.2$ & 90 & 116 & Е.05 & 8.2 & 14.2 & 18.4 \\
\hline WR1849 & $<.04$ & $<1.2$ & 56 & 185 & .26 & .6 & 2.6 & 3.8 \\
\hline
\end{tabular}

${ }^{1}$ EX, Essex County; FU, Fulton County; H, Hamilton County; RE, Rensselaer County; SA, Saratoga County; W, Washington County; WR, Warren County. 
Table A5. Concentrations of trace elements and radionuclide activities in groundwater samples collected in the Upper Hudson River Basin, New York, 2007. _Continued

[ $\mu \mathrm{g} / \mathrm{L}$, micrograms per liter; (01062), U.S. Geological Survey National Water Information System parameter code; <, less than; E, estimated value; M, presence verified but not quantified. Bold values exceed one or more drinking-water standard. Well locations are shown in fig. 2.]

\begin{tabular}{|c|c|c|c|c|c|c|c|c|}
\hline $\begin{array}{c}\text { Well } \\
\text { number1 }\end{array}$ & $\begin{array}{c}\text { Molybdenum, } \\
\text { unfiltered, } \\
\mu \mathrm{g} / \mathrm{L} \\
(01062)\end{array}$ & $\begin{array}{c}\text { Nickel, } \\
\text { unfiltered, } \\
\mu \mathrm{g} / \mathrm{L} \\
(01067)\end{array}$ & $\begin{array}{c}\text { Selenium, } \\
\text { unfiltered, } \\
\mu \mathrm{g} / \mathrm{L} \\
(01147) \\
\end{array}$ & $\begin{array}{c}\text { Strontium, } \\
\text { unfiltered, } \\
\mu \mathrm{g} / \mathrm{L} \\
(01082) \\
\end{array}$ & $\begin{array}{c}\text { Thallium, } \\
\text { unfiltered, } \\
\mu \mathrm{g} / \mathrm{L} \\
(01059)\end{array}$ & $\begin{array}{c}\text { Zinc, } \\
\text { unfiltered, } \\
\mu \mathrm{g} / \mathrm{L} \\
(01092)\end{array}$ & $\begin{array}{c}\text { Radon-222, } \\
\text { unfiltered, } \\
\text { picoCuries } \\
\text { per liter } \\
(82303) \\
\end{array}$ & $\begin{array}{c}\text { Uranium, } \\
\text { unfiltered, } \\
\mu \mathrm{g} / \mathrm{L} \\
(28011)\end{array}$ \\
\hline \multicolumn{9}{|c|}{ Sand and gravel wells } \\
\hline EX159 & 0.7 & $<0.16$ & Е 0.06 & 77.1 & $<0.18$ & $<2.0$ & 100 & 0.224 \\
\hline FU273 & E.1 & .55 & .22 & 402 & $<.18$ & 4.2 & 330 & .380 \\
\hline H296 & M & $<.12$ & $<.08$ & 229 & $<.08$ & 2.1 & 290 & .058 \\
\hline RE889 & E.1 & .16 & .13 & 182 & $<.08$ & 2.3 & 940 & .197 \\
\hline RE1768 & .8 & .30 & .17 & 248 & $<.08$ & E 1.4 & 200 & .771 \\
\hline SA879 & .1 & .21 & $<.08$ & 22.0 & $<.18$ & 5.6 & 280 & .021 \\
\hline SA2742 & .2 & .32 & $<.08$ & 198 & Е.04 & E 1.3 & 180 & .257 \\
\hline SA3644 & $<.1$ & Е .09 & $<.08$ & 178 & $<.18$ & 2.4 & 330 & .368 \\
\hline SA4024 & .4 & 1.9 & $<.08$ & 386 & $<.18$ & 7.4 & 480 & .330 \\
\hline SA4987 & .2 & Е .08 & E.04 & 142 & $<.08$ & 214 & 60 & .147 \\
\hline W1419 & 1.0 & .18 & .14 & 217 & $<.08$ & E 1.8 & 130 & .448 \\
\hline WR83 & .2 & .52 & E.05 & 90.3 & $<.18$ & 25.4 & 520 & 2.01 \\
\hline WR85 & .1 & .20 & $<.08$ & 247 & $<.08$ & $<2.0$ & 280 & .367 \\
\hline \multicolumn{9}{|c|}{ Bedrock wells } \\
\hline EX797 & 2.0 & .16 & $<.08$ & 377 & $<.18$ & 2.0 & 120 & .372 \\
\hline EX1143 & 1.5 & .60 & .15 & 406 & $<.08$ & 5.4 & 70 & .137 \\
\hline H56 & 1.1 & .19 & E.06 & 157 & $<.18$ & 3.9 & 720 & 1.56 \\
\hline H401 & .7 & E.15 & $<.08$ & 90.2 & $<.18$ & $<2.0$ & 1,550 & 3.39 \\
\hline H453 & 1.1 & .28 & .13 & 47.3 & $<.18$ & 10.2 & 1,080 & .282 \\
\hline RE2694 & 4.6 & 1.8 & $<.08$ & 426 & $<.18$ & 3.2 & 20 & .164 \\
\hline SA4346 & 37.8 & .22 & $<.08$ & 234 & $<.08$ & $<2.0$ & 70 & $<.020$ \\
\hline W1274 & .4 & .80 & .54 & 471 & $<.08$ & 8.3 & 1,010 & 1.27 \\
\hline W1284 & 8.3 & 1.0 & $<.08$ & 712 & $<.08$ & $<2.0$ & 120 & 1.22 \\
\hline WR1106 & 1.2 & E.10 & $<.08$ & 83.2 & $<.08$ & 3.1 & 110 & .227 \\
\hline WR1280 & 2.4 & E .14 & $<.08$ & 341 & $<.18$ & 32.4 & 1,340 & 1.88 \\
\hline WR1849 & 2.2 & 55.3 & $<.08$ & 34.2 & $<.18$ & $<2.0$ & 2,930 & .555 \\
\hline
\end{tabular}

${ }^{1}$ EX, Essex County; FU, Fulton County; H, Hamilton County; RE, Rensselaer County; SA, Saratoga County; W, Washington County; WR, Warren County. 
Table A6. Concentrations of pesticides detected in groundwater samples collected in the Upper Hudson River Basin, New York, 2007.

[ $\mu \mathrm{g} / \mathrm{L}$, micrograms per liter; ESA, ethanesulfonic acid; SA, secondary amide; CIAT, 2-chloro-4-isopropylamino-6-amino-striazine; OA, oxanilic acid; (62850), U.S. Geological Survey National Water Information System parameter code; <, less than; E, estimated value; $\mathrm{M}$, presence verified but not quantified. Bold values indicate detections. Well locations are shown in fig. 2.]

\begin{tabular}{|c|c|c|c|c|c|c|c|c|c|c|}
\hline $\begin{array}{c}\text { Well } \\
\text { number }^{1}\end{array}$ & $\begin{array}{c}\text { Acetochlorl } \\
\text { Metolachlor } \\
\text { ESA SA, } \\
\text { filtered, } \\
\mu \mathrm{g} / \mathrm{L} \\
(62850)\end{array}$ & $\begin{array}{c}\text { CIAT, } \\
\text { filtered, } \\
\mu \mathrm{g} / \mathrm{L} \\
(04040)\end{array}$ & $\begin{array}{c}\text { Alachlor } \\
\text { ESA, } \\
\text { filtered, } \\
\mu \mathrm{g} / \mathrm{L} \\
(50009)\end{array}$ & $\begin{array}{c}\text { Atrazine, } \\
\text { filtered, } \\
\mu \mathrm{g} / \mathrm{L} \\
(\mathbf{3 9 6 3 2})\end{array}$ & $\begin{array}{c}\text { Dicamba, } \\
\text { filtered, } \\
\mu \mathrm{g} / \mathrm{L} \\
(\mathbf{3 8 4 4 2 )} \\
\end{array}$ & $\begin{array}{c}\text { Fipronil, } \\
\text { filtered, } \\
\mu \mathrm{g} / \mathrm{L} \\
(62166)\end{array}$ & $\begin{array}{c}\text { Metalaxyl, } \\
\text { filtered, } \\
\mu \mathrm{g} / \mathrm{L} \\
(50359)\end{array}$ & $\begin{array}{c}\text { Metolachlor } \\
\text { ESA, } \\
\text { filtered, } \\
\mu \mathrm{g} / \mathrm{L} \\
(61043) \\
\end{array}$ & $\begin{array}{c}\text { Metolachlor } \\
\text { OA, } \\
\text { filtered, } \\
\mu \mathrm{g} / \mathrm{L} \\
(61044) \\
\end{array}$ & $\begin{array}{c}\text { Simazine, } \\
\text { filtered, } \\
\mu \mathrm{g} / \mathrm{L} \\
(04035)\end{array}$ \\
\hline \multicolumn{11}{|c|}{ Sand and gravel wells } \\
\hline EX159 & $<0.02$ & $<0.014$ & $<0.02$ & $<0.007$ & $<0.08$ & $<0.016$ & $<0.04$ & $<0.02$ & $<0.02$ & $<0.006$ \\
\hline FU273 & $<.02$ & $<.014$ & $<.02$ & $<.007$ & $<.08$ & $<.016$ & $<.04$ & .08 & $<.02$ & $<.006$ \\
\hline H296 & $<.02$ & $<.014$ & .02 & $<.007$ & $<.04$ & $<.020$ & $<.02$ & $<.02$ & $<.02$ & $<.006$ \\
\hline RE889 & $<.02$ & $<.014$ & .02 & $<.007$ & $<.04$ & $<.020$ & $<.02$ & $<.02$ & $<.02$ & $<.006$ \\
\hline RE1768 & $<.02$ & E.002 & .03 & E.002 & $<.04$ & $<.020$ & $<.02$ & $<.02$ & $<.02$ & $<.006$ \\
\hline SA879 & $<.02$ & $<.014$ & $<.02$ & $<.007$ & $<.08$ & $<.016$ & $<.04$ & $<.02$ & $<.02$ & $<.006$ \\
\hline SA2742 & $<.02$ & $<.014$ & $<.02$ & $<.007$ & $<.04$ & E.004 & $<.02$ & $<.02$ & $<.02$ & $<.006$ \\
\hline SA3644 & $<.02$ & $<.014$ & $<.02$ & $<.007$ & .26 & $<.016$ & $<.04$ & $<.02$ & $<.02$ & $<.006$ \\
\hline SA4024 & $<.02$ & $<.014$ & .03 & $<.007$ & $<.08$ & $<.016$ & $<.04$ & .05 & .02 & $<.006$ \\
\hline SA4987 & $<.02$ & $<.014$ & $<.02$ & $<.007$ & $<.04$ & $<.020$ & $<.02$ & $<.02$ & $<.02$ & $<.006$ \\
\hline W1419 & $<.02$ & $<.014$ & $<.02$ & $<.007$ & $<.04$ & $<.020$ & $<.02$ & $<.02$ & $<.02$ & $<.006$ \\
\hline WR83 & $<.02$ & $<.014$ & $<.02$ & $<.007$ & $<.08$ & $<.016$ & $<.04$ & $<.02$ & $<.02$ & $<.006$ \\
\hline WR85 & $<.02$ & E.002 & $<.02$ & E .006 & $<.04$ & $<.020$ & $<.02$ & $<.02$ & $<.02$ & E.005 \\
\hline \multicolumn{11}{|c|}{ Bedrock wells } \\
\hline EX797 & $<.02$ & $<.014$ & $<.02$ & $<.007$ & $<.08$ & $<.016$ & $<.04$ & $<.02$ & $<.02$ & $<.006$ \\
\hline EX1143 & $<.02$ & $<.014$ & $<.02$ & $<.007$ & $<.04$ & $<.020$ & $<.02$ & $<.02$ & $<.02$ & $<.006$ \\
\hline H56 & $<.02$ & $<.014$ & $<.02$ & $<.007$ & $<.08$ & $<.016$ & $<.04$ & $<.02$ & $<.02$ & $<.006$ \\
\hline H401 & $<.02$ & $<.014$ & $<.02$ & $<.007$ & $<.08$ & $<.016$ & $<.04$ & $<.02$ & $<.02$ & $<.006$ \\
\hline H453 & $<.02$ & $<.014$ & $<.02$ & $<.007$ & $<.08$ & $<.016$ & $<.04$ & $<.02$ & $<.02$ & $<.006$ \\
\hline RE2694 & $<.02$ & $<.014$ & $<.02$ & $<.007$ & $<.08$ & $<.016$ & $<.04$ & $<.02$ & $<.02$ & $<.006$ \\
\hline SA4346 & $<.02$ & $<.014$ & $<.02$ & $<.007$ & $<.04$ & $<.020$ & $<.02$ & $<.02$ & $<.02$ & $<.006$ \\
\hline W1274 & .09 & E .002 & .07 & $<.007$ & $<.04$ & $<.020$ & $<.02$ & 1.47 & .27 & $<.006$ \\
\hline W1284 & $<.02$ & $<.014$ & .02 & $<.007$ & $<.04$ & $<.020$ & $<.02$ & .07 & .02 & $<.006$ \\
\hline WR1106 & $<.02$ & $<.014$ & $<.02$ & $<.007$ & $<.04$ & $<.020$ & $<.02$ & $<.02$ & $<.02$ & $<.006$ \\
\hline WR1280 & $<.02$ & $<.014$ & $<.02$ & $<.007$ & $<.08$ & $<.016$ & $<.04$ & $<.02$ & $<.02$ & $<.006$ \\
\hline WR1849 & $<.02$ & $<.014$ & $<.02$ & $<.007$ & $<.08$ & $<.016$ & $\mathbf{M}$ & $<.02$ & $<.02$ & $<.006$ \\
\hline
\end{tabular}

${ }^{1}$ EX, Essex County; FU, Fulton County; H, Hamilton County; RE, Rensselaer County; SA, Saratoga County; W, Washington County; WR, Warren County. 
Table A7. Concentrations of volatile organic compounds and phenolic compounds detected in groundwater samples collected in the Upper Hudson River Basin, New York, 2007.

[ $\mu \mathrm{g} / \mathrm{L}$, micrograms per liter; (32101), U.S. Geological Survey National Water Information System parameter code; <, less than. Bold values indicate detections. Well locations are shown in fig. 2.]

\begin{tabular}{|c|c|c|c|c|c|c|c|}
\hline $\begin{array}{c}\text { Well } \\
\text { number }\end{array}$ & $\begin{array}{c}\text { Bromo- } \\
\text { dichloro- } \\
\text { methane, } \\
\text { unfiltered, } \\
\mu \mathrm{g} / \mathrm{L} \\
(32101)\end{array}$ & $\begin{array}{c}\text { Dibromo- } \\
\text { chloro- } \\
\text { methane, } \\
\text { unfiltered, } \\
\mu \mathrm{g} / \mathrm{L} \\
(32105)\end{array}$ & $\begin{array}{c}\text { Methyl tert- } \\
\text { butyl ether, } \\
\text { unfiltered, } \\
\mu \mathrm{g} / \mathrm{L} \\
(78032)\end{array}$ & $\begin{array}{c}\text { Tetrachloro- } \\
\text { ethene, } \\
\text { unfiltered, } \\
\mu \mathrm{g} / \mathrm{L} \\
(34475) \\
\end{array}$ & $\begin{array}{c}\text { Toluene, } \\
\text { unfiltered, } \\
\mu \mathrm{g} / \mathrm{L} \\
(34010)\end{array}$ & $\begin{array}{c}\text { Trichloro- } \\
\text { methane, } \\
\text { unfiltered, } \\
\mu \mathrm{g} / \mathrm{L} \\
(32106) \\
\end{array}$ & $\begin{array}{c}\text { Total } \\
\text { phenolic } \\
\text { compounds, } \\
\text { unfiltered, } \\
\mu \mathrm{g} / \mathrm{L} \\
(32730) \\
\end{array}$ \\
\hline \multicolumn{8}{|c|}{ Sand and gravel wells } \\
\hline EX159 & $<0.1$ & $<0.2$ & $<0.2$ & $<0.1$ & $<0.1$ & $<0.1$ & $<4$ \\
\hline FU273 & $<.1$ & $<.2$ & $<.2$ & $<.1$ & $<.1$ & .2 & $<4$ \\
\hline H296 & .2 & $<.2$ & $<.2$ & $<.1$ & $<.1$ & .5 & $<4$ \\
\hline RE889 & .2 & $<.2$ & $<.2$ & $<.1$ & $<.1$ & .4 & $<4$ \\
\hline RE1768 & $<.1$ & $<.2$ & $<.2$ & $<.1$ & $<.1$ & .1 & $<4$ \\
\hline SA879 & $<.1$ & $<.2$ & $<.2$ & $<.1$ & $<.1$ & $<.1$ & $<4$ \\
\hline SA2742 & $<.1$ & $<.2$ & .3 & $<.1$ & $<.1$ & .5 & $<4$ \\
\hline SA3644 & $<.1$ & $<.2$ & $<.2$ & $<.1$ & $<.1$ & $<.1$ & $<4$ \\
\hline SA4024 & $<.1$ & $<.2$ & 1.0 & $<.1$ & $<.1$ & $<.1$ & $<4$ \\
\hline SA4987 & $<.1$ & $<.2$ & $<.2$ & $<.1$ & $<.1$ & $<.1$ & $<4$ \\
\hline W1419 & $<.1$ & $<.2$ & $<.2$ & $<.1$ & $<.1$ & $<.1$ & $<4$ \\
\hline WR83 & .3 & .2 & $<.2$ & $<.1$ & $<.1$ & .3 & $<4$ \\
\hline WR85 & $<.1$ & $<.2$ & $<.2$ & .3 & $<.1$ & 1.0 & $<4$ \\
\hline \multicolumn{8}{|c|}{ Bedrock wells } \\
\hline EX797 & $<.1$ & $<.2$ & $<.2$ & $<.1$ & $<.1$ & $<.1$ & $<4$ \\
\hline EX1143 & $<.1$ & $<.2$ & $<.2$ & $<.1$ & $<.1$ & $<.1$ & $<4$ \\
\hline H56 & $<.1$ & $<.2$ & 4.2 & $<.1$ & $<.1$ & .2 & $<4$ \\
\hline H401 & $<.1$ & $<.2$ & $<.2$ & $<.1$ & $<.1$ & $<.1$ & $<4$ \\
\hline H453 & $<.1$ & $<.2$ & $<.2$ & $<.1$ & $<.1$ & $<.1$ & $<4$ \\
\hline RE2694 & $<.1$ & $<.2$ & $<.2$ & $<.1$ & $<.1$ & $<.1$ & $<4$ \\
\hline SA4346 & $<.1$ & $<.2$ & $<.2$ & $<.1$ & $<.1$ & $<.1$ & 5.1 \\
\hline W1274 & $<.1$ & $<.2$ & $<.2$ & $<.1$ & $<.1$ & $<.1$ & $<4$ \\
\hline W1284 & $<.1$ & $<.2$ & $<.2$ & $<.1$ & $<.1$ & $<.1$ & $<4$ \\
\hline WR1106 & $<.1$ & $<.2$ & $<.2$ & $<.1$ & $<.1$ & $<.1$ & $<4$ \\
\hline WR1280 & $<.1$ & $<.2$ & $<.2$ & $<.1$ & $<.1$ & $<.1$ & $<4$ \\
\hline WR1849 & $<.1$ & $<.2$ & $<.2$ & $<.1$ & 1.1 & $<.1$ & $<4$ \\
\hline
\end{tabular}

${ }^{1}$ EX, Essex County; FU, Fulton County; H, Hamilton County; RE, Rensselaer County; SA, Saratoga County; W, Washington County; WR, Warren County. 
Table A8. Bacteria in groundwater samples collected in the Upper Hudson River Basin, New York, 2007.

[CFU, colony-forming unit; mL, milliliter; (31691), U.S. Geological Survey National Water Information System parameter code; <, less than. Well locations are shown in fig. 2.]

\begin{tabular}{|c|c|c|c|c|}
\hline $\begin{array}{c}\text { Well } \\
\text { number }{ }^{1} \\
\end{array}$ & $\begin{array}{c}\text { Escherichia coli, } \\
\text { unfiltered, } \\
\text { CFU/100mL } \\
(31691) \\
\end{array}$ & $\begin{array}{c}\text { Fecal coliform, } \\
\text { unfiltered, } \\
\text { CFU/100mL } \\
(61215)\end{array}$ & $\begin{array}{c}\text { Heterotrophic plate } \\
\text { count, } \\
\text { unfiltered, } \\
\text { CFU/mL } \\
\text { (31692) } \\
\end{array}$ & $\begin{array}{l}\text { Total coliform, } \\
\text { unfiltered, } \\
\text { CFU/100mL } \\
(61213)\end{array}$ \\
\hline \multicolumn{5}{|c|}{ Sand and gravel wells } \\
\hline EX159 & $<1$ & $<1$ & 1 & $<1$ \\
\hline FU273 & $<1$ & $<1$ & 5 & $<1$ \\
\hline H296 & $<1$ & $<1$ & $<1$ & $<1$ \\
\hline RE889 & $<1$ & $<1$ & $<1$ & $<1$ \\
\hline RE1768 & $<1$ & $<1$ & $<1$ & $<1$ \\
\hline SA879 & $<1$ & $<1$ & $<1$ & $<1$ \\
\hline SA2742 & $<1$ & $<1$ & $<1$ & $<1$ \\
\hline SA3644 & $<1$ & $<1$ & $<1$ & $<1$ \\
\hline SA4024 & $<1$ & $<1$ & $<1$ & $<1$ \\
\hline SA4987 & $<1$ & $<1$ & 52 & $<1$ \\
\hline W1419 & $<1$ & $<1$ & $<1$ & $<1$ \\
\hline WR83 & $<1$ & $<1$ & $<1$ & $<1$ \\
\hline WR85 & $<1$ & $<1$ & $<1$ & $<1$ \\
\hline \multicolumn{5}{|c|}{ Bedrock wells } \\
\hline EX797 & $<1$ & $<1$ & 7 & $<1$ \\
\hline EX1143 & $<1$ & $<1$ & $<1$ & $<1$ \\
\hline H56 & $<1$ & $<1$ & $<1$ & $<1$ \\
\hline H401 & $<1$ & $<1$ & 47 & 24 \\
\hline H453 & $<1$ & $<1$ & 2 & $<1$ \\
\hline RE2694 & $<1$ & $<1$ & 16 & $<1$ \\
\hline SA4346 & $<1$ & $<1$ & 1 & $<1$ \\
\hline W1274 & $<1$ & $<1$ & 4 & $<1$ \\
\hline W1284 & $<1$ & $<1$ & $<1$ & $<1$ \\
\hline WR1106 & $<1$ & $<1$ & $<1$ & $<1$ \\
\hline WR1280 & $<1$ & $<1$ & $<1$ & $<1$ \\
\hline WR1849 & $<1$ & $<1$ & 252 & $<1$ \\
\hline
\end{tabular}

${ }^{1}$ EX, Essex County; FU, Fulton County; H, Hamilton County; RE, Rensselaer County; SA, Saratoga County; W, Washington County; WR, Warren County. 
This page has been left blank intentionally. 
For more information concerning this report, contact

\section{Director}

U.S. Geological Survey

New York Water Science Center

425 Jordan Road

Troy, NY 12180-8349

dc_ny@usgs.gov

or visit our Web site at: http://ny.water.usgs.gov 
